2012

\title{
The Effect of Oral Care on Intracranial Pressure in Critically III
}

\section{Adults}

Christina Szabo

Virginia Commonwealth University

Follow this and additional works at: https://scholarscompass.vcu.edu/etd

Part of the Nursing Commons

() The Author

\section{Downloaded from}

https://scholarscompass.vcu.edu/etd/330

This Dissertation is brought to you for free and open access by the Graduate School at VCU Scholars Compass. It has been accepted for inclusion in Theses and Dissertations by an authorized administrator of VCU Scholars Compass. For more information, please contact libcompass@vcu.edu. 
(C) Christina Marie Szabo 2012

All Rights Reserved 
The Effect of Oral Care on Intracranial Pressure in Critically Ill Adults

A dissertation submitted in partial fulfillment of the requirements for the degree of Doctor of Philosophy at Virginia Commonwealth University.

Christina Marie Szabo, RN, MS, CNRN, CCRN

VCU Chair: Mary Jo Grap, PhD, RN, FAAN

Professor, Adult Health and Nursing Systems

School of Nursing

Virginia Commonwealth University

Richmond, Virginia

April, 2012 


\section{Acknowledgments}

The author wishes to thank several people. I would like to thank my husband for his support during this project. I would like to thank my children, Aaron, Carmella and Ian for their patience and understanding. I would like to thank my dissertation committee for their help and guidance with this project. I would like to thank the patients and families of the Neuroscience ICU. Last

but not least, I would like to thank my friends and colleagues in the Neuroscience Intensive Care Unit. 


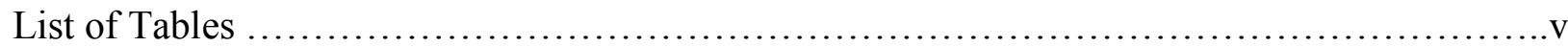

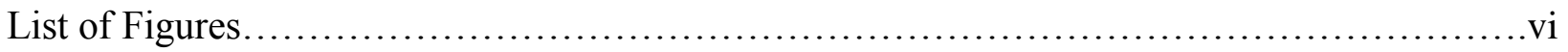

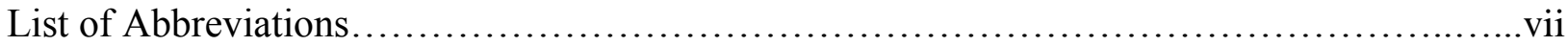

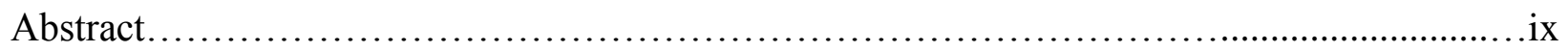

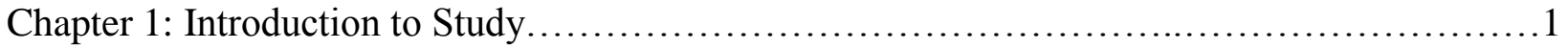

Chapter 2: The Effect of Oral Care on Intracranial Pressure: A Review of the Literature.........6

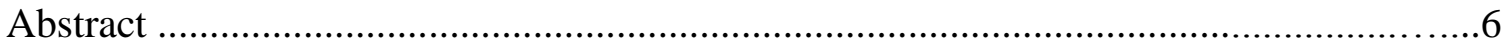

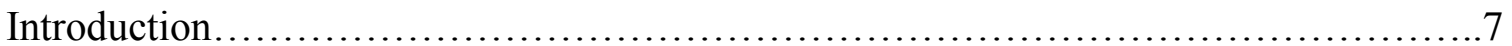

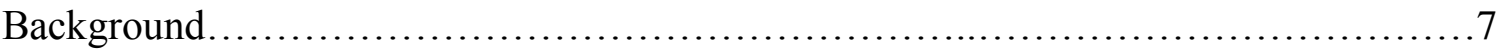

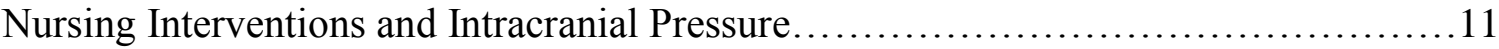

Conclusion............................................................21

Chapter 3: The Effect of Oral Care on Intracranial Pressure in Critically Ill Adults............23

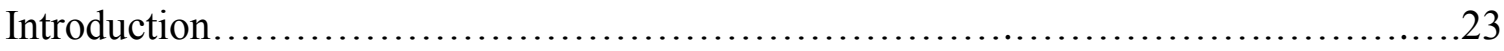

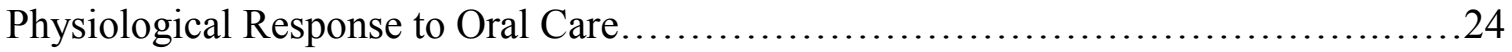

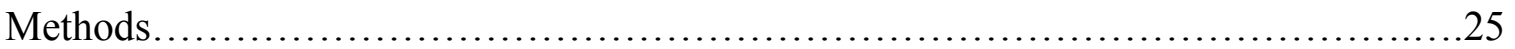

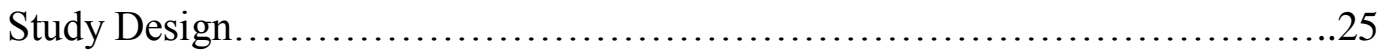

Setting and Sample..................................................... 25

Procedure..........................................................26 
Observation of Oral Care ...........................................26

ICP Monitoring..................................................

Observational Rating of Oral Care Intensity.........................28

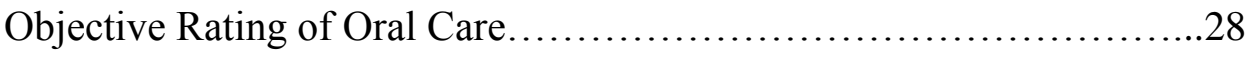

Duration of Oral Care...............................................29

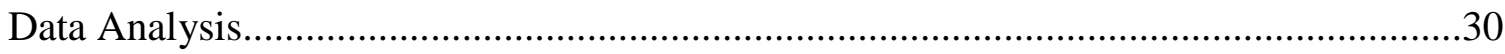

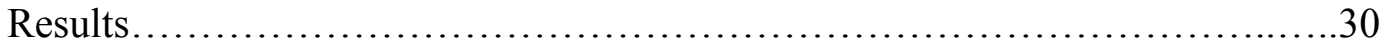

Patient Characteristics.............................................. 30

Oral Care Intervention........................................34

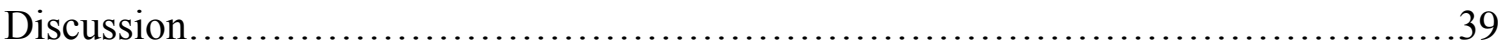

Conclusion..............................................................41

References...................................................................... 42

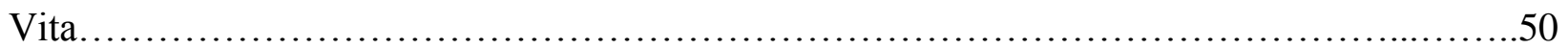


List of Tables

Table 1. Studies Investigating the Effect of Nursing Interventions on ICP....................13

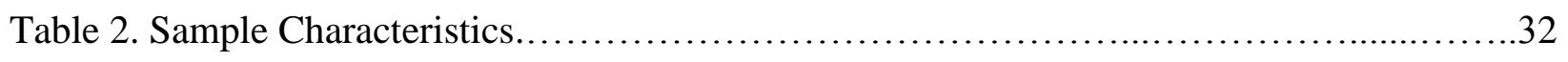

Table 3. Mean Baseline Physiological Measures 24 Hours Before Observation.................33

Table 4. Oral Care Products Used...................................................... 34

Table 5. LS Mean Differences in ICP and CPP Before, During and After Oral Care..............37 
List of Figures

Figure 1. Conceptual Model...................................................4

Figure 2. Box 1. Concepts relevant to cerebral hemodynamics.............................9

Figure 3. Study Flowchart..........................................................

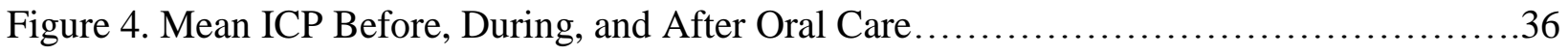

Figure 5. Examples of nurses' wrist actigraphy recordings during oral care by observational

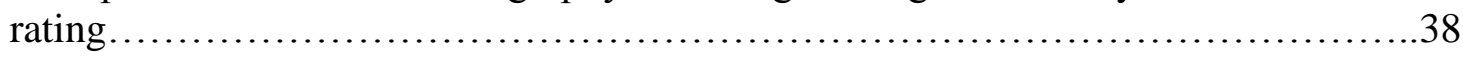




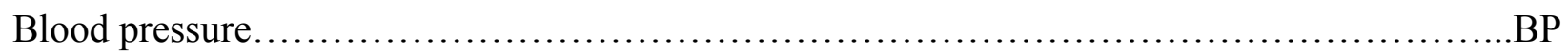

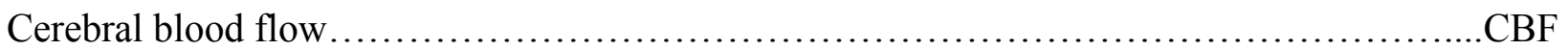

Cerebral blood volume........................................................

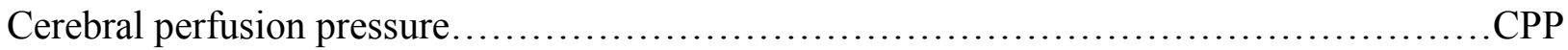

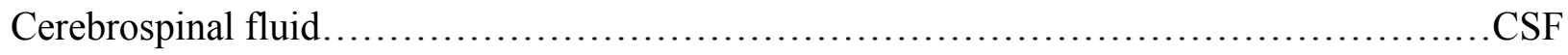

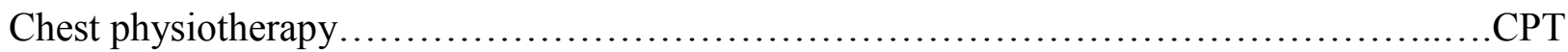

End tidal carbon dioxide......................................................

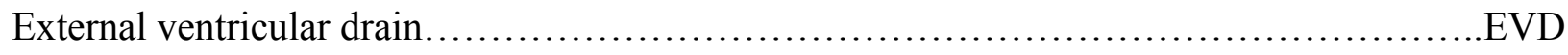

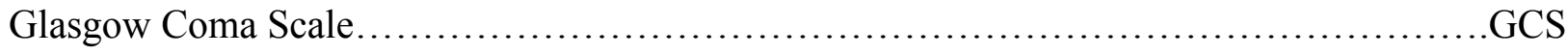

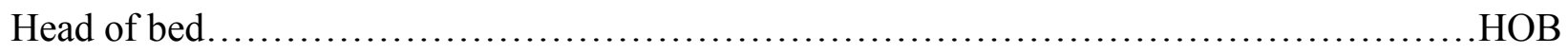

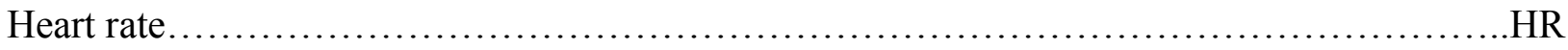

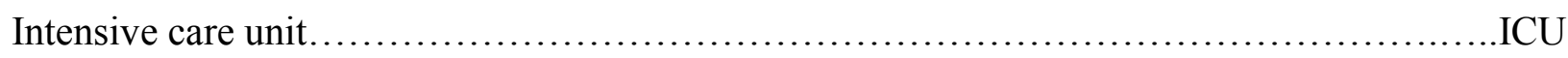

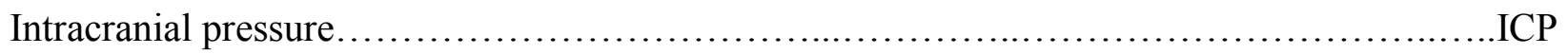

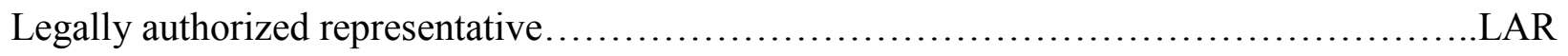

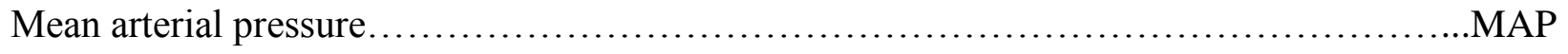

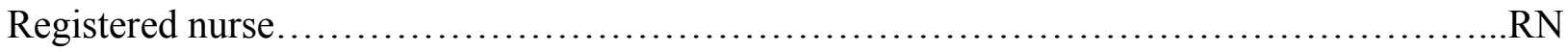




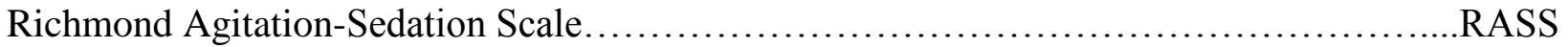

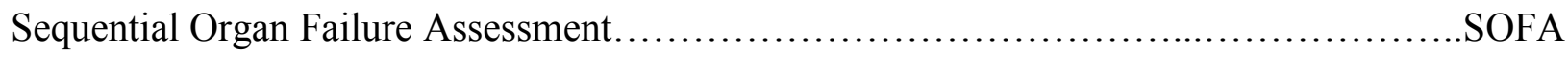

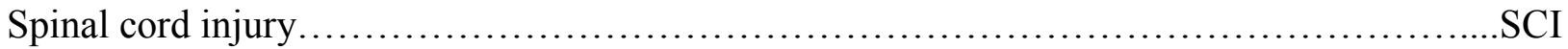

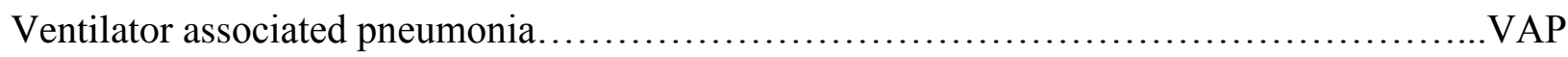




\begin{abstract}
THE EFFECT OF ORAL CARE ON INTRACRANIAL PRESSURE IN CRITICALLY ILL ADULTS

By Christina M. Szabo, RN, MS, CCRN, CNRN
\end{abstract}

A dissertation submitted in partial fulfillment of the requirements for the degree of Doctor of Philosophy at Virginia Commonwealth University.

Virginia Commonwealth University, 2012

VCU Chair: Mary Jo Grap, PhD, RN, FAAN

Professor, Adult Health and Nursing Systems

School of Nursing

A major goal in the care of patients with neurological problems is to prevent or minimize episodes of increased intracranial pressure (ICP). Elevations in ICP in response to nursing interventions have been acknowledged since the 1960's when ICP monitoring was first introduced in the clinical setting. Until recently few studies have specifically examined the effect of oral care on ICP and oral care and other hygiene measures were combined or not specified, prohibiting a direct interpretation of the influence of oral care alone on ICP. The purpose of this study was to describe the relationship between routine oral care interventions and 
the changes in ICP specifically focusing on the effect of intensity and duration of this intervention.

Twenty-three patients with a clinical condition requiring ICP monitoring were enrolled over a 12 month period. Oral care provided by neuroscience intensive care nurses was observed and videotaped. Characteristics of the intervention were documented including products used, patient positioning, and duration of the intervention. A 1-5 subjective scale was used to score intensity of oral care. Wrist actigraphy data were collected from the nurses to provide an objective measure of intensity. Patient physiologic data were collected at 12 second epochs 5 minutes before, during and 5 minutes after oral care. The mixed effect repeated measures ANOVA model indicated that there was a statistically significant increase in ICP in response to oral care $(p=0.0031)$. There was, however, no clinically significant effect on ICP. This study provides evidence that oral care is safe to perform in patients in the absence of pre-existing elevated ICP. 


\section{Chapter 1: Introduction to the Study}

Management of intracranial pressure (ICP) is a central focus for nursing care of neurologically compromised critically ill patients. Increased ICP is a potentially life threatening complication that may arise following traumatic and nontraumatic brain injuries (Wolfe \& Torbey, 2009; Frattalone \& Stevens, 2011). Many essential nursing care interventions can result in elevations in ICP, but the effects of nurse-provided oral care have not been well studied. This research examined the effect of oral care on ICP and related physiological parameters.

ICP represents the pressure exerted by the brain, blood and cerebrospinal fluid within the cranial vault. It is a dynamic process that fluctuates in response to the changing volume and size of the intracranial contents. The normal range of ICP is $0-20 \mathrm{mmHg}$ and is considered critically elevated at values greater than $20 \mathrm{mmHg}$. Intracranial hypertension, more commonly referred to as increased ICP, is defined as a sustained elevation of 20mmHg (Hickey \& Olson, 2009). Increased ICP, whether due to traumatic brain injury, ischemia, hemorrhage, tumor or infection, can result in significant mortality and morbidity. It is estimated that in the traumatic brain injury population, intracranial hypertension due to cerebral edema accounts for over half of the mortality and morbidity in these patients (Donkin \& Vink, 2010; May, 2009). Management of increased ICP is a central focus for neuroscience clinicians.

ICP monitoring is accomplished by implanting a device through a surgical opening in the skull into the epidural, subdural or subarachnoid space or directly into the brain tissue or lateral cerebral ventricle. There are several different types of monitoring devices and all measure the 
sum of the pressures exerted by the contents of the cranial vault within the skull. All create an electrical signal that is transmitted to a monitor that displays a numeric value and waveform. ICP monitors placed in the ventricles can also be used to drain and sample cerebrospinal fluid and to administer medication (Littlejohns \& Bader, 2009).

ICP monitoring has been used since the 1960's to guide the treatment of patients with neurological conditions. In the 1970's nurses began reporting on the influence of nursing care activities on ICP (Mitchell, 1986). These studies have shown that nursing care activities can lead to increased ICP and this body of knowledge has been used to develop a variety of nursing care guidelines for patients with or at risk for developing increased ICP (Szabo, 2011; Thompson, 2011).

Patients who require intracranial pressure monitoring are typically admitted to intensive care units (ICU). These patients are critically ill and may have invasive lines and tubes so their care is directed by many guidelines, not just those aimed at ICP management. The various guidelines may not take ICP management into consideration so must be adapted by the nurse in the patient with elevated ICP. Such may be the case with oral care, a routine nursing intervention in the ICU. Recent emphasis on oral care and its hypothesized association with the prevention of ventilator associated pneumonia (VAP) in the critically ill has led to the development of recommendations and guidelines that aim to standardize this intervention (American Association of Critical-Care Nurses, 2010). While the use of an oral antiseptic to reduce the risk of VAP has been validated (Institute for Healthcare Improvement, 2009; Munro et al., 2009), the risks and benefits of toothbrushing and other oral care products are less well understood. Despite the number of well designed studies on oral care in the critically ill, there remains a need to evaluate 
the safety of various oral care interventions in specific ICU patient populations (Ames, 2011). For neuroscience ICU patients, an important measure of safety is the effect of oral care on ICP. A conceptual model of the relationships between oral care and factors that contribute to intracranial pressure changes is shown in Figure 1. During oral care somatosensory information from the oral cavity, lips and face is transmitted via cranial nerves 5, 7,9 and 10 via the thalamus to the cerebral cortex. Stimulation of these nerves during oral care may contribute to the ICP response through cerebral metabolic activation which requires increased cerebral blood flow to meet the metabolic demand (Branston, 1995). The maxillary division of CN 5 innervates upper portion of oral cavity and skin over the cheek and the mandibular division innervates skin over the jaw and above the ear, lower part of the oral cavity and tongue. Taste sensation from the anterior two-thirds of the tongue is transmitted by CN 7. The autonomic component of $\mathrm{CN} 7$ contains sympathetic fibers that innervate submandibular and sublingual salivary glands. CN 9 is responsible for taste sensation in the posterior one-third of the tongue, sensation from posterior palate and $\mathrm{CN} 10$ transmits sensation from the posterior pharynx. Touch receptors in the tongue and lips detect movement between this tissue and a surface (such as a toothbrush) and mediate the ability to perceive shape and form. Free nerve endings in oral facial tissue detect temperature and noxious stimuli. While the contents of the intracranial vault influence the ICP superimposed on these are complex networks of neurons located in the brainstem that participate in the regulation of cardiovascular and respiratory functions. While there are vital sign "centers" in the brainstem, cardiac and respiratory centers are not located in specific areas of the brainstem but are intermingled, functionally related, have reciprocal connections and respond to input from the central, peripheral, and autonomic nervous systems (Breedlove, 2007). Oral care may affect ICP via one or more of these systems. 


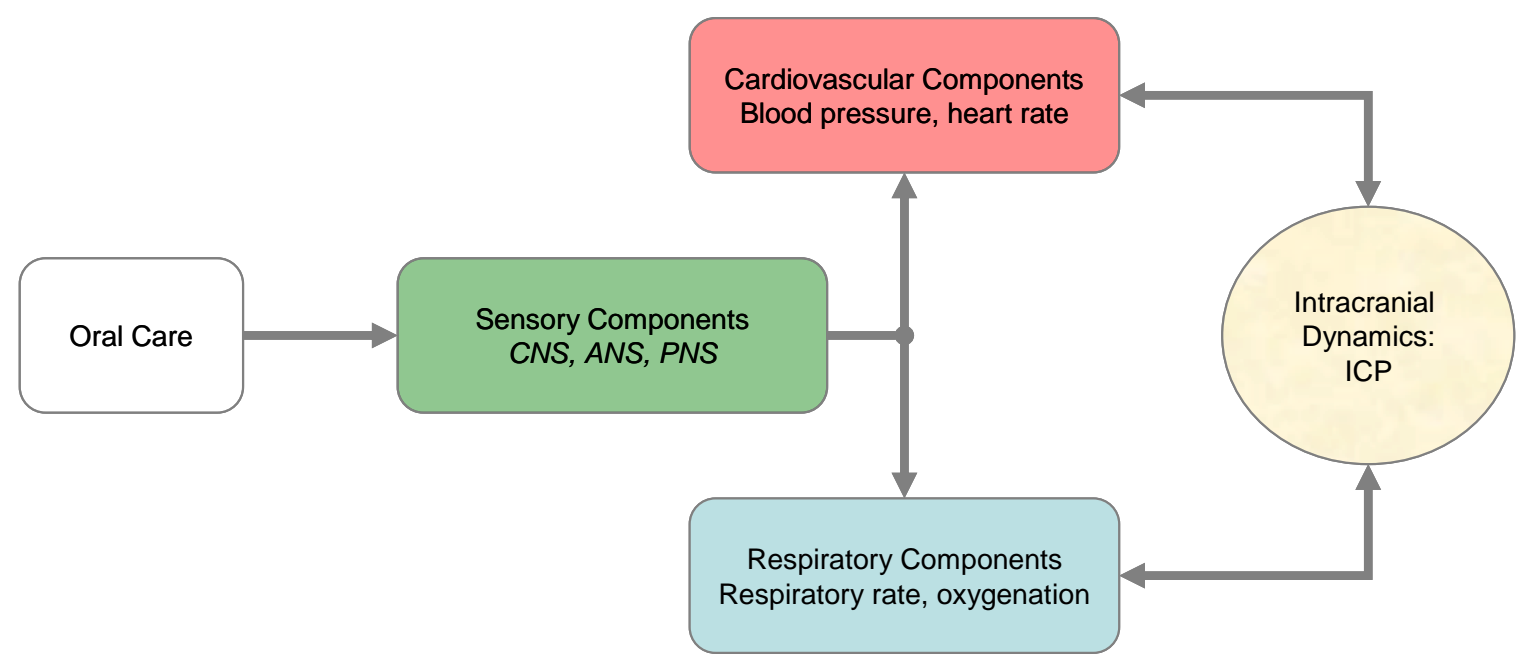

Figure 1. Conceptual Model

Chapter 2 provides comprehensive review of the literature related to the effect of routine nursing interventions on ICP. When published in the American Journal of Neuroscience Nurses (Szabo, 2011), only 4 studies specifically examined oral care and in these, oral care was not specifically described or paired with other routine hygiene measures. Since then, one study has been published that found a statistically significant increase in ICP in response to oral care (Prendergast, 2011).

Chapter 3 presents the findings of an observational, descriptive study of the effect of oral care on ICP. This study examined the ICP response to oral care based on the duration and intensity of the intervention. Oral care was isolated from all other nursing care activities in order to evaluate the contribution of oral care alone on changes in ICP. We compared ICP, cerebral perfusion pressure, heart rate, blood pressure, respiratory rate and pulse oximetry values 5 minutes before, during and 5 minutes after oral care. We found a statistically significant increase in ICP from before to after oral care $(\mathrm{p}=0.0031)$. This increase was small $(2.13 \mathrm{mmHg})$ and not 
clinically significant in that no patient required additional interventions to reduce ICP. There was no relationship between the increase in ICP and oral care intensity or duration. We concluded that this study provides evidence that nurse-administered oral care does not adversely effect ICP. 


\title{
Chapter 2. The effect of oral care on intracranial pressure: A review of the literature
}

This article is reprinted with the permission of the Journal of Neuroscience Nursing, published by Wolters Kluwer Health, Christina M. Szabo, The effect of oral care on intracranial pressure: A review of the literature, October, 2011, Vol. 43(5),pp. E1-E9,

license number 2854850231556.

\begin{abstract}
Neuroscience intensive care unit nurses routinely perform oral care on patients with intracranial pressure (ICP) monitoring. When the ICP is elevated or rises in response to oral care, this intervention may be withheld despite the lack of evidence linking the two. In order to appraise the best evidence for providing oral care to patients with intracranial pressure monitoring, articles published from 1978 to 2009 in English and indexed in CINHAL, PubMed/MEDLINE, Cochran Library and BioSys were searched using the key terms intracranial pressure monitoring, intracranial hypertension, oral care, mouth care, hygiene, nursing interventions, nursing care, intensive care and critical care. Reference lists of retrieved articles were reviewed for articles missed during the initial search. The search yielded 65 articles: 16 experimental/quasi-experimental studies, 24 descriptive studies, and 25 review articles. Of these, only 4 specifically tested or described the effect of oral care on ICP. There is a need for more knowledge about the effect of oral care on ICP so that evidence-based oral care practices in this patient population can be defined.
\end{abstract}




\section{Introduction}

Minimizing elevations in intracranial pressure (ICP) is a significant challenge in critically ill neuroscience patients, especially when the interventions that increase ICP are necessary to prevent additional complications. In providing care to critically ill patients requiring ICP monitoring, nurses balance the need for an intervention with the risk of causing elevation in ICP. They anticipate the physiological response to the intervention before it is initiated. A common approach is to note the ICP responses to all interventions before proceeding with a specific intervention. If the ICP increases beyond normal limits, the intervention is stopped or modified in order to prevent further elevation. Such is the case with oral care, a routine intervention frequently included in efforts to decrease ventilator associated pneumonia. Nurses indicate that oral care is a priority and modify their oral practices based on the ICP. It is important to understand the ICP response to oral care in order to develop strategies for modifying this intervention. There are few studies, however, that have systematically explored the effect of oral care on ICP. This paper will provide a comprehensive review of the state of the science in the study of the effect on ICP of nursing interventions similar to oral care and the implication for oral care practices.

\section{Background}

Continuous intracranial monitoring has become the standard of care for patients with conditions associated with increased ICP. Intracranial pressure reflects the pressure exerted by the contents of the cranium (blood, brain, and cerebrospinal fluid) against the bony, rigid skull which, under normal conditions, are in a state of dynamic equilibrium. In adults, the normal range for ICP is $5-15 \mathrm{mmHg}$. It is considered elevated at values greater than $20 \mathrm{mmHg}$. According to the Monro-Kellie doctrine, if an increase in one of the intracranial components is 
not matched by a reciprocal decrease in one or both of the others the result is increased ICP, or intracranial hypertension.

Intracranial pathology that is known to increase ICP includes traumatic brain injury, intracranial hemorrhage, ischemic stroke, tumor, abscess, meningitis, encephalitis, increased production of cerebrospinal fluid (CSF), decreased absorption of CSF and obstruction of CSF flow. Extracranial pathology includes hypoxia, hypercarbia, fever, hypertension, hyponatremia, venous obstruction and hepatic failure (Ropper \& Rockhoff, 1993). Normal compensatory mechanisms to reduce ICP include displacement of CSF from the brain to the subarachnoid cistern, compression of the venous sinuses and vasoconstriction of cerebral arteries, which results in decreased cerebral blood volume (Hickey \& Olson, 2009).

The critical issue in management of patients with intracranial hypertension is cerebral perfusion. The brain receives approximately $15 \%$ to $20 \%$ of the total cardiac output and consumes $20 \%$ of all oxygen used by the body. Given the brain's high metabolic rate and oxygen demands, systemic mean arterial pressure (MAP) is a factor in maintaining cerebral perfusion. (Kandel et al., 2000). Concepts relevant to cerebral hemodynamics are listed in Box 1 (Boss, 2002). 


\section{Cerebral Hemodynamics}

Cerebral Blood Volume (CBV) is the amount of blood circulating in the brain at a given time, most of which is in the low pressure venous system. CBV is maintained through autoregulation, a complex mechanism that regulates blood vessel diameter in order to maintain a constant blood flow

Cerebral Blood Flow (CBF) must be sufficient to match the metabolic demands of the brain; normal CBF is approximately $750 \mathrm{ml} / \mathrm{minute}$ and is regulated by constriction and dilation of the cerebral vessels in response to changes in arterial oxygen and carbon dioxide concentrations

Cerebral Perfusion Pressure (CPP) is calculated by subtracting the ICP from the MAP (CPP=MAP-ICP). The normal CPP in adults is $70 \mathrm{mmHg}-100 \mathrm{mmHg}$. In order to maintain an adequate CPP, an increase in ICP must be matched by an increase in CPP.

[Figure 2.] Box 1. Concepts relevant to cerebral hemodynamics 
Minimizing elevations in ICP and maintaining cerebral perfusion pressure is a significant challenge in critically ill patients, especially when interventions that are necessary for patient care and to prevent complications increase ICP. The association between nursing care activities and the onset of ICP elevations has been recognized since the beginning of clinical ICP monitoring in the 1960's (Mitchell \& Mauss, 1978). These activities and the hypothesized mechanisms, which are reviewed in depth by Hickey and Olson (2009), include hypoxia and hypercarbia associated with endotracheal suctioning, obstruction of venous flow with neck rotation, increased blood pressure via sympathetic stimulation during painful procedures, and decreased venous return with supine and Trendelenberg positioning. The effect of oral care, however, has not been systematically explored.

For healthy individuals, daily oral hygiene is a self-care activity that contributes to oral health and has aesthetic value related to the individual's appearance and control of breath odor. Under normal circumstances oral care is not generally considered a painful procedure and the individual becomes accustomed to the sensations associated with caring for their own mouth. Over time, people develop patterns of oral care including time spent cleaning surfaces of the teeth and amount of pressure applied (Claydon, 2008). Patients who require ICP monitoring are typically admitted to the intensive care unit where oral care is provided by critical care nurses. Critically ill patients are typically unable to perform their own oral care and nurse provided oral care may be different in terms of equipment and products used, pressure applied to the teeth and gums, and the duration of the oral care. The effect of these differences on the patient's experience of oral care is unknown.

The importance of oral care in critically ill patients has been well described. In addition to contributing to overall health and physical comfort, oral care may play a role in the prevention 
of ventilator-associated pneumonia (VAP). Colonization of dental plaque with potential respiratory pathogens is a risk factor for VAP, an important clinical problem that increases mortality, hospital length of stay and health care costs. As a routine daily intervention, oral care is a priority for all critical care nurses including those who care for patients with neurological conditions. (Munro \& Grap, 2004; Berry \& Davidson, 2006; Munro, Grap, Jones, McClish, \& Sessler, 2009). In a pilot study of oral care and ICP, 21 neuroscience intensive care unit nurses rated oral care high compared to other routine interventions and indicated that the ICP value played an important role in decisions about frequency, duration and intensity of oral care (Szabo $\&$ Munro, in press). This finding was consistent with a study about nursing judgments regarding risk of secondary injury in patients with traumatic brain injury (McNett et al., 2009). Using situational vignettes, the investigators found that physiological variables, including ICP, significantly influenced nurses' assessment of their patient's risk for secondary injury and their approach to managing patients in the face of worsening physiological parameters. In these situations, nurses may modify or delay oral care despite a lack of evidence to support this decision. In a study of changes in Oral Assessment Guide scores and the development of ventilator associated pneumonia in neuroscience intensive care unit patients, Prendergast and colleagues (2009) found no adverse effect of oral care on ICP but note that the nurses in their study may have decided not to perform oral care when the ICP was elevated. Given the competing priorities of preventing increases in ICP and providing necessary oral care, the relationship between the two is important.

\section{Nursing Interventions and Intracranial Pressure}

Nursing care of the critically ill involves a variety of routine interventions including managing the environment, bathing, turning, suctioning, positioning and providing oral hygiene. 
The first step in deciding how and when to perform these activities in patients with, or at risk for intracranial hypertension, is anticipation of their effect on ICP. There are a number of studies that have investigated the effect of nursing interventions and patient activities on ICP (Table 1). While these works are used in the development of guidelines for the nursing care of neuroscience patients, the majority are non-experimental and the sample sizes are small. There are few studies that specifically investigate the effect of oral care on ICP. In these studies, oral care was either not considered separately from other hygiene measures or the oral care intervention was not fully described. Tsementzis, Harris, and Loizou (1982) studied the effect of routine nursing care on ICP in severely head injured patients. In this study, oral care was paired with skin care as a general hygiene measure and described as "nursing care stimuli" (p. 154).

Bruya (1981) included oral care in a study of the effect of planned rest periods between nursing activities on ICP. The activities were, in order, routine vital signs, suctioning, oral care and bed bath. In the control group, all activities were performed in sequence followed by a rest period, while in the treatment group there was a 10 minute rest period between three sets of activities-vital signs, respiratory care and bed bath. Oral care was included with manual hyperventilation and suctioning in the respiratory care set. 
Table 1. Studies Investigating the Effect of Nursing Interventions on ICP

\begin{tabular}{|c|c|c|c|c|c|}
\hline Reference & Aim & Sample & Design Method & Results & Limitations \\
\hline \multicolumn{6}{|c|}{ Chest Physiotherapy } \\
\hline $\begin{array}{l}\text { (Olson et al., } \\
\text { 2007) }\end{array}$ & $\begin{array}{l}\text { To report ICP } \\
\text { changes associated } \\
\text { with mechanical } \\
\text { chest physiotherapy } \\
(\mathrm{CPT})\end{array}$ & $\begin{array}{l}1 \text { patient with a } \\
\text { severe closed } \\
\text { head injury and } \\
\text { ventilator } \\
\text { associated } \\
\text { pneumonia }\end{array}$ & Case study & $\begin{array}{l}\text { - Mean ICP trended downward } \\
\text { with CPT } \\
\text { - Changes in mean values for } \\
\text { ICP before, during and after } \\
\text { mechanical CPT were } \\
\text { statistically and clinically } \\
\text { significant }\end{array}$ & $\begin{array}{l}\text { - Unknown } \\
\text { mechanism to } \\
\text { account for ICP } \\
\text { changes } \\
\text { Did not explore } \\
\text { confounding } \\
\text { variables }\end{array}$ \\
\hline $\begin{array}{l}\text { (Olson DM, } \\
\text { 2009) }\end{array}$ & $\begin{array}{l}\text { To explore the safety } \\
\text { of CPT in patients at } \\
\text { risk for elevated ICP }\end{array}$ & $\begin{array}{l}28 \text { critically ill } \\
\text { patients with at } \\
\text { least one } \\
\text { episode of } \\
\text { elevated ICP }\end{array}$ & $\begin{array}{l}\text { Randomized control } \\
\text { trial }\end{array}$ & $\begin{array}{l}\text { - No significant difference in } \\
\text { mean ICP in patients who } \\
\text { received } 10 \text { minutes of } \\
\text { mechanical CPT compared to } \\
\text { those who received no CPT }\end{array}$ & - $\quad$ Small sample size \\
\hline \multicolumn{6}{|c|}{ Turning, Head and Neck Position } \\
\hline (Hugo, 1992) & $\begin{array}{l}\text { To describe the effect } \\
\text { of manual turning } \\
\text { and head of bed } \\
\text { elevation on ICP }\end{array}$ & $\begin{array}{l}23 \text { severely } \\
\text { head injured } \\
\text { patients }\end{array}$ & Descriptive & $\begin{array}{l}\text { - Greatest ICP increases noted } \\
\text { when patients turned to left } \\
\text { lateral position } \\
\text { - Statistically significant } \\
\text { correlation between elevated } \\
\text { ICP and more frequent nursing } \\
\text { interventions }\end{array}$ & $\begin{array}{ll}\text { - } & \text { Small sample size } \\
\text { - } & \text { Most patients } \\
\text { positioned with } \\
\text { head of bed at } 45 \\
\text { degrees, no } \\
\text { comparison of } \\
\text { position change at } \\
\text { different HOB } \\
\text { elevations }\end{array}$ \\
\hline
\end{tabular}




\begin{tabular}{|c|c|c|c|c|c|}
\hline (Ng et al., 2004) & $\begin{array}{l}\text { To compare the effect } \\
\text { of no head elevation } \\
\text { to } 30 \text { degrees head } \\
\text { elevation on ICP, } \\
\text { CPP and cerebral } \\
\text { oxygenation }\end{array}$ & $\begin{array}{l}38 \text { severely } \\
\text { head injured } \\
\text { patients }\end{array}$ & $\begin{array}{l}\text { Randomized cross- } \\
\text { over }\end{array}$ & 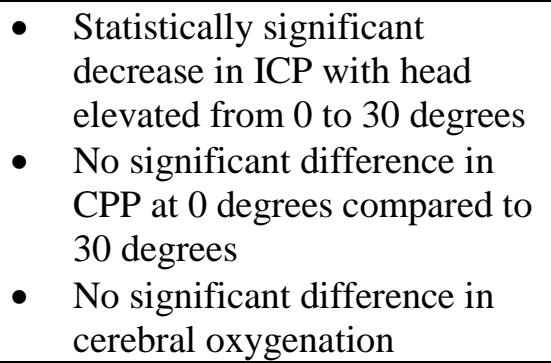 & - $\quad$ Small sample size \\
\hline $\begin{array}{l}\text { (Winkelman, } \\
\text { 2000) }\end{array}$ & $\begin{array}{l}\text { To compare the effect } \\
\text { of no head elevation } \\
\text { to } 30 \text { degrees head } \\
\text { elevation on ICP and } \\
\text { CPP }\end{array}$ & $\begin{array}{l}8 \text { adult patients } \\
\text { with traumatic } \\
\text { brain injury }\end{array}$ & $\begin{array}{l}\text { Randomized cross- } \\
\text { over }\end{array}$ & $\begin{array}{l}\text { ICP was significantly lower } \\
\text { and CPP was significantly } \\
\text { higher at } 30 \text { degree HOB } \\
\text { elevation compared to flat } \\
\text { position }\end{array}$ & - Small sample size \\
\hline (Jones, 1994) & $\begin{array}{l}\text { To identify the } \\
\text { effects of manual } \\
\text { turning from static } \\
\text { position to supine, } \\
\text { right and left side- } \\
\text { lying positions on } \\
\text { ICP }\end{array}$ & $\begin{array}{l}30 \text { critically ill } \\
\text { patients with } \\
\text { traumatic and } \\
\text { atraumatic } \\
\text { neurological } \\
\text { pathology }\end{array}$ & Descriptive & $\begin{array}{l}\text { Group mean ICP increased } \\
\text { with positions change but } \\
\text { changes were not statistically } \\
\text { significant }\end{array}$ & $\begin{array}{l}\text { - Small sample size } \\
\text { - ICP changes during } \\
\text { position changes } \\
\text { could be due to } \\
\text { artifact }\end{array}$ \\
\hline $\begin{array}{l}\text { (Williams \& } \\
\text { Coyne, 1993) }\end{array}$ & $\begin{array}{l}\text { To investigate the } \\
\text { effect of } 4 \text { different } \\
\text { neck positions on ICP }\end{array}$ & $\begin{array}{l}10 \text { critically ill } \\
\text { patients with } \\
\text { neurological } \\
\text { dysfunction }\end{array}$ & $\begin{array}{l}\text { Quasi-experimental } \\
\text { cross-over }\end{array}$ & $\begin{array}{l}\text { - Lowest ICP with head \& neck } \\
\text { in neutral position and neck } \\
\text { extended without rotation } \\
\text { - Highest ICP with head turned } \\
\text { to right }\end{array}$ & $\begin{array}{l}\text { - } \\
\text { - } \\
\text { Did not include } \\
\text { combined positions } \\
\text { of rotation with } \\
\text { neck extension } \\
\end{array}$ \\
\hline $\begin{array}{l}\text { (March et al., } \\
\text { 1990) }\end{array}$ & $\begin{array}{l}\text { To determine the } \\
\text { effect of head of bed } \\
\text { elevation alone, with } \\
\text { knees bent and in } \\
\text { reverse } \\
\text { Trendelenberg on } \\
\text { ICP,CPP, blood } \\
\text { pressure and cerebral } \\
\text { blood flow velocity }\end{array}$ & $\begin{array}{l}4 \text { comatose } \\
\text { head injured } \\
\text { patients }\end{array}$ & $\begin{array}{l}\text { Quasi-experimental } \\
\text { within-subject design }\end{array}$ & $\begin{array}{l}\text { - Changes in ICP,CPP, BP and } \\
\text { cerebral blood flow velocity } \\
\text { related to position changed are } \\
\text { highly individualized }\end{array}$ & - Small sample size \\
\hline
\end{tabular}




\begin{tabular}{|c|c|c|c|c|c|}
\hline $\begin{array}{l}\text { (Parsons \& } \\
\text { Wilson, 1984) }\end{array}$ & $\begin{array}{l}\text { To describe the effect } \\
\text { of turning with and } \\
\text { without flexion of } \\
\text { arms and legs, range } \\
\text { of motion, neck } \\
\text { position and head of } \\
\text { bed elevation on } \\
\text { cerebrovascular } \\
\text { status }\end{array}$ & $\begin{array}{l}18 \text { severely } \\
\text { head injured } \\
\text { patients }\end{array}$ & Descriptive & $\begin{array}{l}\text { Turning, positioning, head } \\
\text { rotation and range of motion } \\
\text { exercises and lowering head of } \\
\text { bed produced increases in heart } \\
\text { rate, mean arterial pressure, } \\
\text { mean ICP and cerebral } \\
\text { perfusion pressure } \\
\text { - Head of bed elevation } \\
\text { produced significant decreases } \\
\text { in mean arterial pressure } \\
\text { (MAP) and mean ICP }\end{array}$ & $\begin{array}{ll}- & \text { Small sample size } \\
\text { - } & \text { All patients not } \\
\text { observed in all } \\
\text { positions }\end{array}$ \\
\hline $\begin{array}{l}\text { (Mitchell et al., } \\
\text { 1981) }\end{array}$ & $\begin{array}{l}\text { To describe the effect } \\
\text { of arm and hip } \\
\text { flexion and } \\
\text { extension, head } \\
\text { rotation and turning } \\
\text { on ICP }\end{array}$ & $\begin{array}{l}19 \text { critically ill } \\
\text { patients with } \\
\text { neurological } \\
\text { dysfunction }\end{array}$ & $\begin{array}{l}\text { Quasi-experimental, } \\
\text { cross-over }\end{array}$ & $\begin{array}{l}\text { - No significant differences in } \\
\text { ICP with range of motion } \\
\text { exercises } \\
\text { - Significant increase in ICP } \\
\text { with turning and head rotation } \\
\text { - Cumulative increase in ICP } \\
\text { with activities performed } \\
\text { within } 15 \text { minutes of each } \\
\text { other }\end{array}$ & - Small sample size \\
\hline
\end{tabular}




\begin{tabular}{|c|c|c|c|c|c|}
\hline \multicolumn{6}{|c|}{ Endotracheal Suctioning } \\
\hline $\begin{array}{l}\text { Brucia \& Rudy, } \\
1996\end{array}$ & $\begin{array}{l}\text { To determine effect } \\
\text { of suction catheter } \\
\text { insertion and tracheal } \\
\text { insertion on ICP, } \\
\text { MAP, CPP and HR }\end{array}$ & $\begin{array}{l}30 \text { severely } \\
\text { head injured } \\
\text { patients }\end{array}$ & $\begin{array}{l}\text { Quasi-experimental, } \\
\text { within-subject design } \\
\text { using existing data } \\
\text { from previous study }\end{array}$ & $\begin{array}{l}\text { - Statistically significant } \\
\text { elevation in ICP, MAP and } \\
\text { CPP during catheter insertion } \\
\text { - Statistically significant } \\
\text { increase in ICP during } \\
\text { suctioning compared to } \\
\text { catheter insertion } \\
\text { - No significant change in heart } \\
\text { rate during catheter insertion or } \\
\text { suctioning }\end{array}$ & - Small sample size \\
\hline
\end{tabular}




\begin{tabular}{|c|c|c|c|c|c|}
\hline $\begin{array}{l}\text { (Parsons \& } \\
\text { Wilson, 1984) }\end{array}$ & $\begin{array}{l}\text { To describe the } \\
\text { effects of an } \\
\text { endotracheal } \\
\text { suctioning protocol } \\
\text { including manual } \\
\text { hyperventilation on } \\
\text { ICP, MAP, CPP and } \\
\text { HR }\end{array}$ & $\begin{array}{l}20 \text { severely } \\
\text { head injured } \\
\text { patients }\end{array}$ & Descriptive & $\begin{array}{l}\text { - Statistically significant } \\
\text { elevations in mean ICP, MAP, } \\
\text { CPP and HR during procedure } \\
\text { No statistically significant } \\
\text { difference in baseline mean } \\
\text { ICP, MAP, CPP or HR } \\
\text { compared to recovery values }\end{array}$ & - $\quad$ Small sample size \\
\hline \multicolumn{6}{|c|}{ Family Visitation } \\
\hline (Prins, 1989) & $\begin{array}{l}\text { To describe the effect } \\
\text { of family visitation } \\
\text { and the quality of the } \\
\text { visit on ICP using the } \\
\text { Patient-Family } \\
\text { Interaction Scale }\end{array}$ & $\begin{array}{l}15 \text { critically ill } \\
\text { patients with } \\
\text { neurological } \\
\text { dysfunction }\end{array}$ & Descriptive & $\begin{array}{l}\text { No statistically significant } \\
\text { difference in ICP before, } \\
\text { during, or after family visit } \\
\text { No significant correlation } \\
\text { between PFIS score and ICP } \\
\text { during visit }\end{array}$ & $\begin{array}{ll}\text { - } & \text { Small sample size } \\
\text { - } & \text { Validity and } \\
& \text { reliability of PFIS } \\
\text { not established, } \\
\text { Poor internal } \\
\text { consistency }(\mathrm{r}=.30) \\
\end{array}$ \\
\hline $\begin{array}{l}\text { (Schinner et al., } \\
1995 \text { ) }\end{array}$ & $\begin{array}{l}\text { To test the effect of } 3 \\
\text { different auditory } \\
\text { stimuli-silence } \\
\text { achieved with } \\
\text { earplugs, music and } \\
\text { ambient ICU noise- } \\
\text { on ICP and CPP }\end{array}$ & $\begin{array}{l}15 \text { severely } \\
\text { head injured } \\
\text { patients }\end{array}$ & $\begin{array}{l}\text { Experimental, cross- } \\
\text { over }\end{array}$ & $\begin{array}{l}\text { No statistically or clinically } \\
\text { significant difference in ICP } \\
\text { with any of the auditory } \\
\text { interventions at day } 2 \text { or day } 4 \\
\text { post injury }\end{array}$ & $\begin{array}{ll}\text { Short duration of } \\
\text { ICP/CPP } \\
\text { monitoring } \\
\text { following } \\
\text { intervention } \\
\text { - } 73 \% \text { of patients } \\
\text { received sedative } \\
\text { - } \text { Earplugs and } \\
\text { earphones used for } \\
\text { music intervention } \\
\text { may have been } \\
\text { uncomfortable }\end{array}$ \\
\hline
\end{tabular}




\begin{tabular}{|c|c|c|c|c|c|}
\hline $\begin{array}{l}\text { (Walker et al., } \\
\text { 1998) }\end{array}$ & $\begin{array}{l}\text { To study the effects } \\
\text { of taped messages } \\
\text { by a family member } \\
\text { on ICP, BP, MAP, } \\
\text { HR, respiratory rate } \\
\text { (RR), pulse } \\
\text { oximetry and level } \\
\text { of restlessness }\end{array}$ & $\begin{array}{l}10 \text { severely } \\
\text { head injured } \\
\text { comatose } \\
\text { patients }\end{array}$ & $\begin{array}{l}\text { Quasi-experimental, } \\
\text { repeated measures }\end{array}$ & $\begin{array}{l}\text { No statistically significant } \\
\text { difference in ICP, HR, BP, } \\
\text { MAP, RR or pulse oximetry } \\
\text { before, during or after } \\
\text { playing the tape } \\
\text { Restless was observed in } \\
\text { half of the subjects but no } \\
\text { patterns observed. }\end{array}$ & $\begin{array}{l}\text { - } \text { Small sample size } \\
\text { - Did not establish } \\
\text { baseline auditory } \\
\text { function }\end{array}$ \\
\hline $\begin{array}{l}\text { (Treloar et al., } \\
\text { 1991) }\end{array}$ & $\begin{array}{l}\text { To investigate the } \\
\text { effect of familiar } \\
\text { (family member) and } \\
\text { unfamiliar } \\
\text { (researcher) voices on } \\
\text { ICP }\end{array}$ & $\begin{array}{l}12 \text { severely } \\
\text { head injured } \\
\text { patients }\end{array}$ & $\begin{array}{l}\text { Quasi-experimental } \\
\text { repeated measures }\end{array}$ & $\begin{array}{l}\text { No statistically significant } \\
\text { differences before, during or } \\
\text { after familiar and unfamiliar } \\
\text { voice interventions }\end{array}$ & $\begin{array}{ll}- & \text { Small sample size } \\
\text { - } & \text { Did not establish } \\
\text { baseline auditory } \\
\text { function } \\
\text { - No randomization } \\
\text { of treatment } \\
\text { sequencing, all } \\
\text { subjects received } \\
\text { familiar voice } \\
\text { treatment first } \\
\end{array}$ \\
\hline
\end{tabular}


ICP increased with all activities including oral care, but the clustering makes it difficult to interpret the contribution of oral care alone to increased ICP.

In one of two published studies isolating oral care from other hygiene measures, Hugo (1987) also examined the effect of rest periods between activities and the effect on ICP but extended the rest period to 30 minutes. Nursing activities observed were bed bath, repositioning, bronchial toilet, oral hygiene, and testing pupil reactions to light. All produced increases in ICP, but the investigator noted the difficulty in studying nursing activities that followed in rapid succession, specifically citing the sequence of bathing, oral hygiene and turning.

Parsons, Peard, and Page (1985) investigated the effect of standardized oral hygiene, body hygiene and indwelling urinary catheter care on heart rate, mean arterial blood pressure, mean ICP and CPP. Oral hygiene was broadly defined as "any procedure to clean the mouth, oropharynx and/or throat" (p. 175) but specific techniques and products were not described. The frequency of oral hygiene was every 2 to 4 hours; duration was not described. All 3 hygiene interventions produced statistically significant increases in physiologic variables, with the largest increases occurring with oral and body hygiene. The investigators theorized that the increases associated with oral care were possibly due to head position or manipulation of the endotracheal tube during the procedure.

Body positions that reduce venous flow from the head increase the total intracranial blood volume and therefore have the potential to increase ICP. Optimal body positioning during oral care in patients with neurological dysfunction is unknown. Head of bed elevation to 30 degrees is the recommended position for patients with brain injury (Fan, 2004; Hugo, 1992; March et al., 1990; Ng et al., 2004; Simmons, 1997; Winkelman, 2000) but recent studies in acute ischemic stroke patients indicate that a lower head of bed position may be preferred. 
Despite slightly higher ICP measurements in this patient population, cerebral blood flow velocity was higher when patients were flat (Schwarz et al., 2002a; Wojner et al., 2002; WojnerAlexander et al., 2005).

Neutral neck alignment is also a recommended position for patients with intracranial hypertension. Lipe and Mitchell (1980) demonstrated a clear effect of neck rotation on internal jugular vein blood flow velocity. In a study using healthy volunteers, the investigators found that 90 degree head rotation partially or completely occluded the jugular vein. Studies on the relationship between ICP and neck rotation in patients with a variety of neurological conditions demonstrate marked increases in ICP with this maneuver (Mitchell et al., 1981; Parsons \& Wilson, 1984; Williams \& Coyne, 1993). During oral care the nurse may turn the patient's head in order to access the posterior oral cavity which potentially, and inadvertently, may be detrimental.

Oral care in the critically ill may be complicated by the presence of an endotracheal tube. Simple manipulation of the tube may stimulate a cough reflex (Mitchell \& Mauss, 1978) with coughing during endotracheal tube suctioning which can have adverse effects including increased ICP, MAP and CPP (Brucia \& Rudy, 1996; Crosby \& Parsons, 1992; Kerr et al., 1993; Kerr et al., 1997).

Noxious stimuli are known to cause increased ICP and a number of investigators have studied the effect of various stimuli on ICP dynamics. Brucia and Rudy (1996) demonstrated that tracheal stimulation during the passage of a suction catheter prior to the commencement of endotracheal suctioning produced significant increases in ICP and CPP. Nurse-initiated conversations with or about patients that occur at the bedside, a source of auditory stimuli, have been shown to produce elevations in ICP (Mitchell \& Mauss, 1978; Snyder, 1983). Other types 
of auditory stimuli, including audio-taped recordings of messages and various sounds, however, have not been shown to produce significant increases in ICP (Johnson et al., 1989; Schinner et al., 1995; Treloar et al., 1991; Walker et al., 1998). The few studies on chest physiotherapy (Olson et al., 2007; Olson DM, 2009), a source of physical stimulation, have shown that this treatment does not significantly increase ICP. The studies described above demonstrate that the response to a presumed noxious stimulus is highly variable and the effect of oral care cannot be predicted from them.

\section{Conclusion}

There are several mechanisms by which oral care may produce elevations in ICP. Neck position and manipulation of the endotracheal tube during oral care may be contributing factors. Stimulation of cranial nerves that innervate the oral mucosa, peridontium, tooth pulp, tongue, lips, and cheeks lead to activation of the autonomic nervous system and can result in increased arousal, changes in heart rate and systemic blood pressure which ultimately affects intracranial pressure (Kandel et al., 2000). Consequently, the duration and amount of pressure applied to the teeth and gums are important considerations when nurses perform oral care.

Oral care is an important nursing intervention in the care of patients with increased ICP. However, the effect of oral care on ICP has not been fully elucidated and must be extrapolated from what is known about the relationships between other nursing care activities and ICP elevations. Without an established research base for best practices, oral care methods used by critical care nurses remain poorly defined and inconsistent (Berry \& Davidson, 2006; Binkley et al., 2004; Jones et al., 2004; Munro \& Grap, 2004) and a lower priority compared to other nursing interventions (Berry et al., 2007; Grap et al., 2003; Hanneman \& Gusick, 2005). Oral care methods employed by critical care nurses need to be understood in terms of the products 
used (toothbrush, foam swab, toothpaste, mouthwash, water, saline and antibacterial oral solution) and technique (pattern, force and duration).

The need for foundational knowledge about oral care and ICP which could establish a standardized approach to oral care while minimizing the impact on ICP in this patient population is essential since nurses make decisions about when and how to provide oral care based on the patient's ICP. Investigation of the effect of oral care on ICP is a logical next step in this line of inquiry in order to design and test strategies to minimize the detrimental effects of oral care on ICP elevations. For example, does the duration of oral care affect ICP? Is the intervention inherently stimulating or is there a threshold of oral care performance time over which the effects are magnified? Is the force applied by the nurse to teeth and gums related to the magnitude of ICP change (i.e., is "gentler" care better)? Specifically, such data will provide empirical evidence for the most appropriate oral care in the critically ill neuroscience patient. 


\section{Chapter 3. The Effect of Oral Care on Intracranial Pressure in Critically Ill Adults}

\section{Introduction}

Critically ill patients with neurological pathology can experience elevations in intracranial pressure (ICP) which may be associated with the underlying condition or may occur in response to routine nursing interventions. Regardless of the underlying cause, elevated ICP is associated with significant mortality and morbidity (Bratton et al, 2007). Therefore, a major goal in the care of patients with neurological problems is to prevent or minimize episodes of increased ICP. The challenge for critical care nurses is to balance the need for an intervention with the risk of causing increased ICP.

Elevations in ICP in response to nursing interventions have been acknowledged since the 1960's when ICP monitoring was first introduced in the clinical setting (Mitchell \& Mauss, 1978). Previous studies on the effect of routine nursing interventions (hygiene, suctioning, positioning, chest physiotherapy, auditory stimulation, activity and visitation) have significantly influenced care of neuroscience patients. Many of these studies, however, are non-experimental and limited by small sample size (Szabo, 2011). Furthermore, until recently few studies have specifically examined the effect of oral care on ICP (Tsementzis et al., 1982; Parsons, Peard \& Page, 1985; Bruya, 1981; Snyder, 1983) and in these studies oral care and other hygiene measures were combined or occurred in rapid sequence. In most, the oral care procedure and factors that are known to be associated with ICP, specifically body position and neck alignment (Hickey \& Olson, 2009) during oral care were not fully described. Prendergast and colleagues 
(2011) conducted a randomized clinical trial to study the effect of manual and electric toothbrushing on ICP among critically ill, intubated adult neuroscience patients. Patients were assigned to either the manual or electric toothbrush group and ICP was measured before, during and after oral care. There was a statistically significant difference in ICP across time points with both methods but no significant difference between groups. Pooled data from both groups showed a significant difference across time points - a mean increase of $1.7 \mathrm{mmHg}$ between 30 minutes before and during oral care followed by a mean decrease of $2.2 \mathrm{mmHg}$ from during to 30 minutes after oral care. All 47 patients in the study had baseline normal ICP values and there were no clinically significant effects reported. The researchers concluded that oral care was safe in patients with normal ICP values and that additional research is needed to determine the safety of oral care in patients with elevated ICP.

\section{Physiological Response to Oral Care}

During oral care somatosensory information from the oral cavity, lips and face is transmitted via cranial nerves 5, 7, 9 and 10 via the thalamus to the cerebral cortex. Stimulation of these nerves during oral care may contribute to the ICP response (Breedlove, 2007).

Oral care is generally not considered a painful procedure. People become accustomed to the sensations associated with caring for their own mouth. Nurse-administered oral care may be different compared to "self-administered oral care" in terms of products used, intensity and duration. Regardless of duration and/or intensity of nurse -administered oral care, sensory stimulation during oral care stimulates the cerebral cortex which increases metabolic needs of cerebral tissue. Increased cerebral metabolic need results in increased cerebral blood flow which, in turn, affects ICP (Breedlove, 2007). If the patient experiences discomfort during nurseadministered oral care the intervention may activate pain pathways which, through stimulation of 
the autonomic nervous system, causes increased heart rate and blood pressure which ultimately affects ICP. The purpose of this study was to describe the relationship between routine oral care interventions and the changes in ICP that occur during this intervention. Specifically, intensity of oral care was hypothesized to be related to ICP with higher intensity associated with higher ICP. Likewise, the duration of oral care was hypothesized to be related to higher ICP with longer durations associated with higher ICP. Simultaneous measurements of heart rate, blood pressure, respiratory rate and pulse oximetry were also recorded and analyzed. These measures reflect physiological variables that moderate and regulate ICP.

\section{Methods}

\section{Study Design}

This was a nonexperimental observational study of the effect of oral care on ICP. Both patients and nurses were subjects. The study was approved by the institutional review board. Informed consent was obtained from the participant or, for patients not able to provide informed consent, from the legally authorized representative prior to enrollment. Each patient participant was observed for five minutes before, during, and five minutes after a routine nurse-administered oral care intervention. Nurse participants wore wrist mounted motion sensors while providing oral care to the patients in the study.

\section{Setting and Sample}

This study was conducted in a 933-bed tertiary care university teaching hospital in the southeast. Convenience sampling was used and participants were recruited from the neuroscience ICU. Patients 18 years and older were considered eligible for inclusion if they required ICP monitoring and were unable to perform their own oral care. Exclusion criteria included injury to the tongue, lips teeth or gums, fractures of the mandible or maxilla, wired jaws, or concomitant 
spinal cord injury (SCI). There was no requirement that participants be intubated or mechanically ventilated.

\section{Procedure}

Baseline physiological data were obtained 24 hours prior to the observation of oral care. The most recent Glasgow Coma Scale (GCS) and Richmond Agitation-Sedation Scale (RASS) scores were used along with the Sequential Organ Failure Assessment (SOFA) score to describe neurological impairment, sedation level and severity of illness respectively on the day of observation. The GCS score is the most commonly used grading system for coma and is used as a standard measure for the rapid assessment of neurological status. The RASS score is based on a 10 -point scale ranging from +4 to -5 . A score of 0 denotes a calm and alert state, +4 a combative state and -5 indicates that the patient is unarousable (Sessler, et al, 2002; Grap, et al, 2005). SOFA, a scoring system based on a 0-24 scale is a reliable and accurate score that reflects daily severity of organ dysfunction and predicts prognosis and ICU mortality (Arts et al, 2005; Ferreira, et al, 2001; Vincent, et al, 1998; Zygun et al 2003). Higher scores denote more severe organ dysfunction.

\section{Observation of Oral Care}

One or two episodes of routine oral care were observed for each of the 23 subjects. Two episodes of oral care were observed whenever possible in order to describe the effect of the intervention on ICP at various time points relative to the neurological injury. The first observation occurred during the first 48 hours following the initiation of continuous ICP monitoring. When the ICP monitor remained in place $(n=10)$, a second observation occurred 72 to 96 hours following the initiation of monitoring. 
Oral care was recorded using a digital video camcorder (Canon GL2) secured on a tripod placed at the foot of the patient's bed, zoomed to the patient's mouth to capture video for validation of oral care characteristics, including intensity. Patient participants were video recorded for approximately 5 minutes to capture the episode of oral care. So that the oral care episode could be isolated from other routine nursing interventions such as bathing, turning or endotracheal suctioning, to the extent possible, the bedside nurse was asked to avoid these activities during the observation period. Physiologic data were collected for 5 minutes before, during and for 5 minutes after oral care or until another intervention was performed. Throughout the study period physiological variables of heart rate, respiratory rate, systolic, diastolic and mean arterial pressure, ICP and cerebral perfusion pressure (CPP) were collected at 12 second epochs from the bedside monitors (Phillips IntelliVue Patient Monitor MP60/MP70; Software Version F.01.02) ${ }^{\circledR}$. For patients who did not have an arterial pressure monitor line, the CPP was calculated from the last recorded non-invasive mean blood pressure value.

Oral care products, patient body position and neck alignment during the intervention were recorded. The hospital bed (Hill-Rom TotalCare ${ }_{\circledast}$ ) integrated protractor was used to measure head of bed (HOB) elevation.

\section{ICP Monitoring}

ICP was measured using the device present for clinical care of each subject. Monitoring devices included external ventricular devices, an intraparenchymal devices (Codman ${ }^{\circledR}$ ICP Express) or intraparenchymal ICP monitors with a ventricular drainage catheter (Hummingbird ${ }_{\mathrm{TM}}$ Ventricular, Innerspace). All devices create an electrical signal that is transmitted to a monitor which converts the signal into a pressure reading. All devices also transmit a waveform that represents the pulse pressure transmitted to the intracranial compartment by the systemic blood 
pressure (March \& Madden, 2009). For the devices with a ventricular component, leveling to the tragus and zero calibration was performed prior to data collection. For patients with an external ventricular catheter device on continuous drain, the catheter was clamped prior to oral care and remained clamped for 5 minutes following oral care. Throughout the observation period, whether the order was for intermittent or continuous drain, the catheter was opened to drain CSF if the ICP exceeded the clinically prescribed set point.

\section{Observational Rating of Oral Care Intensity}

Intensity of oral care was hypothesized to be related to ICP, with higher intensity associated with higher ICP. For this study, a 1-5 ordinal scale was used to assign a rating to the intensity of the nurse-administered oral care with 1 the lowest intensity and 5 the highest. Characteristics of oral care used to assign the rating were the amount of vertical and horizontal movement of the toothbrush or toothette, speed and tempo of the procedure, depth the toothbrush (or toothette) was passed into the patient's oral cavity and the degree of distension of the patient's lips and cheeks during the intervention. Oral care intensity scores were assigned immediately after the observation by the investigator. Ten percent of the video recordings were reviewed by an unbiased observer and independently scored and there was $100 \%$ agreement on the ratings.

\section{Objective Rating of Oral Care}

To provide an objective measure of oral care intensity, nurses wore a Motionlogger ${ }^{\circledR}$ actigraphy watch (Ambulatory Monitoring, Inc. Ardsley, NY) while performing oral care. Actigraphy has been validated as a tool for evaluation of activity in a variety of behavioral states including sleep and exercise. Actigraphy varies from zero with no activity to values in the hundreds with vigorous activity (Acebo, 2005; Grap, 2005; Leidy, 1997). Actigraphy was used 
to measure gross motor movement activity and to relate the degree and intensity of wrist motion to the observational, ordinal level of oral care intensity. Use of actigraphy was tested in a pilot study to evaluate the feasibility of an oral care intensity measurement tool. In the pilot study, 15 registered nurse volunteered to participate in a project that involved wearing an actigraphy watch while performing researcher defined low, medium and high intensity simulated oral care on a manikin. The lowest average actigraphy values were found with low intensity oral care, higher average values with medium intensity and the highest average values were found with high intensity oral care. Actigraphy patterns for each observation varied based on the researcher provided definitions of low, medium and high intensity. For example, low intensity oral care was described as smooth and slow and this pattern was observed in graphs of the actigraphy data whereas the pattern associated with high intensity oral care was very uneven with wide variation in values.

Actigraphy data were collected using a 1-second time epoch to capture the degree and intensity of the nurses' wrist motion during oral care. Following the oral care intervention, data were downloaded via a USB cable to a computer-based program (ActMillennium, Version 3.47.03, Ambulatory Monitoring, Inc). Actigraphy files were saved as text documents for statistical analysis.

\section{Duration of Oral Care}

In order to temporally relate the physiological parameters to the oral care intervention, the time on the bedside monitor was used as the standard for measuring the duration of oral care events. This allowed for synchronization of oral care duration to the vital signs. Duration was confirmed by viewing the video recordings. 


\section{Data Analysis}

Data were analyzed using the JMP 9.0 Statistical Software (SAS Institute, Cary, NC). All data were summarized using descriptive statistics. A mixed-effects repeated measures analysis of variance (ANOVA) was used to evaluate mean change in physiological variables before, during, after oral care. The model included a fixed effect for time with a random effect for subjects. Linear regression was used to evaluate the relationship between ICP and oral care intensity and duration and to evaluate the relationship between actigraphy values and subjective ratings of oral care. A $p$ value of less than 0.05 was considered statistically significant.

\section{Results}

\section{Patient Characteristics}

Among the 90 patients screened for eligibility, 23 were included in the analysis (Figure 3). Demographic characteristics of the sample are shown in Table 2. 


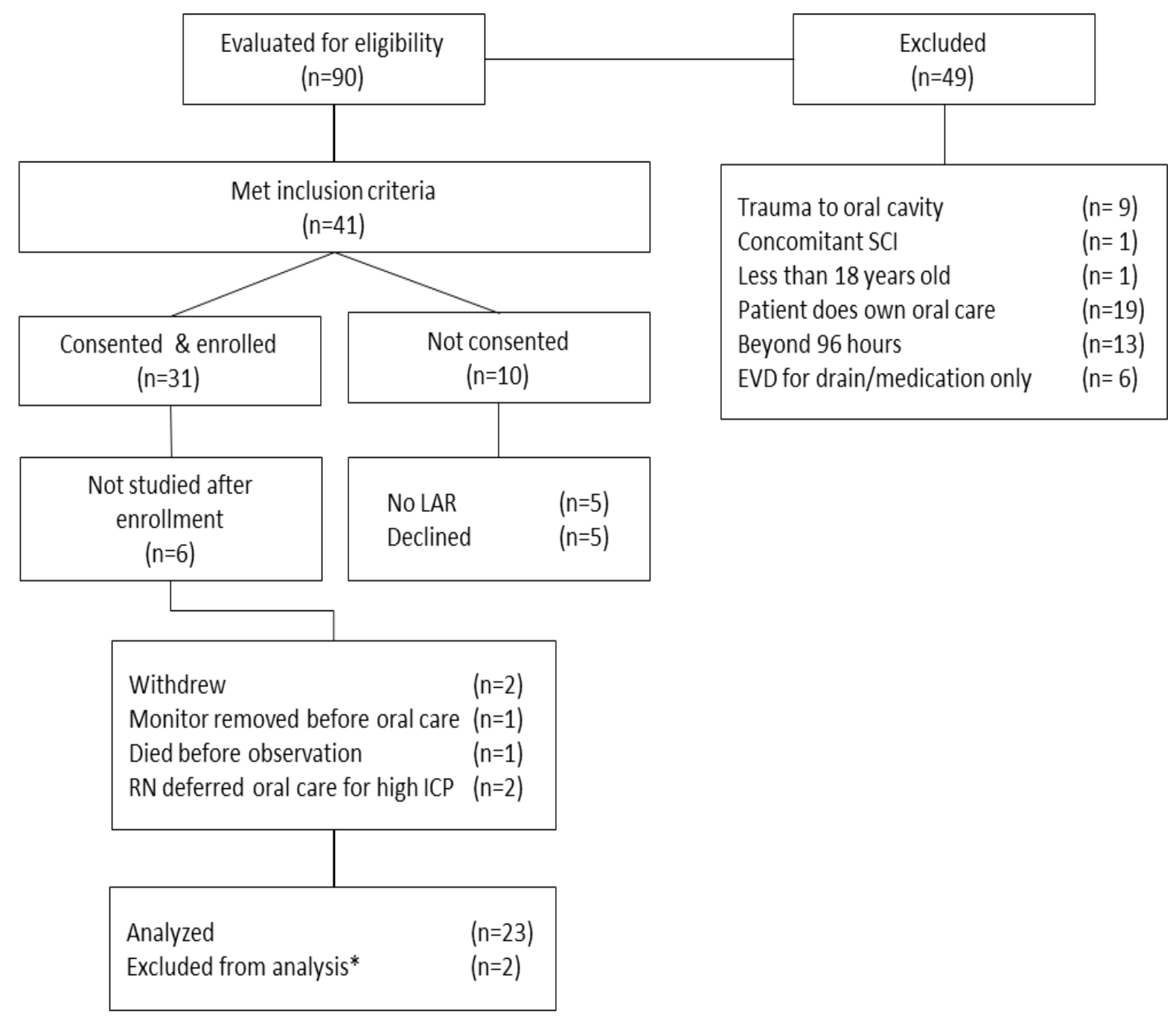

* Monitor displayed negative ICP values which were attributed to measurement error and therefore excluded from analysis

Figure 3. Study Flowchart 
Table 2. Sample Characteristics

\begin{tabular}{|c|c|c|c|}
\hline \multirow[t]{2}{*}{ Variable } & \multicolumn{3}{|c|}{ Value } \\
\hline & Mean & SD & Range \\
\hline \multirow[t]{2}{*}{ Age } & 48.5 & 14.9 & $18-71$ \\
\hline & \multicolumn{2}{|c|}{ Frequency } & $\%$ \\
\hline \multicolumn{4}{|l|}{ Gender } \\
\hline Male & \multicolumn{2}{|c|}{12} & 52 \\
\hline Female & \multicolumn{2}{|c|}{11} & 48 \\
\hline \multicolumn{4}{|l|}{ Ethnicity } \\
\hline African American & \multicolumn{2}{|c|}{12} & 52 \\
\hline White & \multicolumn{2}{|c|}{11} & 48 \\
\hline \multicolumn{4}{|l|}{ Primary Neurological Diagnosis } \\
\hline Traumatic Brain Injury & \multicolumn{2}{|c|}{9} & 39 \\
\hline Subarachnoid Hemorrhage & \multicolumn{2}{|c|}{7} & 30 \\
\hline Intracranial Hemorrhage & \multicolumn{2}{|c|}{5} & 22 \\
\hline Intraventricular Hemorrhage & \multicolumn{2}{|c|}{1} & 4 \\
\hline Tumor & \multicolumn{2}{|c|}{1} & 4 \\
\hline Craniectomy & \multicolumn{2}{|c|}{6} & 26 \\
\hline \multicolumn{4}{|l|}{ Monitor Type } \\
\hline External ventricular device (EVD) & \multicolumn{2}{|c|}{18} & 78 \\
\hline Intraparenchymal & \multicolumn{2}{|c|}{3} & 13 \\
\hline Combined EVD/Intraparenchymal & \multicolumn{2}{|c|}{2} & 9 \\
\hline
\end{tabular}

On the day of observation, the most current indicators of neurological impairment, level of sedation and severity of illness (GCS, RASS and SOFA scores respectively) were recorded. The median GCS was 8, with a range of 3 to 15 , the median RASS score was -2 with a range of 5 to +2 , and the median SOFA score was 4 , range 0 to 10 . Baseline physiological measures are shown in Table 3. 
Table 3. Mean Baseline Physiological Measures 24 Hours Before Observation

\begin{tabular}{|l|c|c|c|}
\hline Variable & Mean & SD & Range \\
\hline ICP & 11.36 & 4.8 & $3-24$ \\
\hline CPP & 78.63 & 14.8 & $53-119$ \\
\hline Heart rate & 91.79 & 15.6 & $66-120$ \\
\hline Respiratory rate & 18.54 & 5.1 & $10-29$ \\
\hline Systolic BP & 140.27 & 18.9 & $105-182$ \\
\hline Diastolic BP & 72.24 & 12.3 & $47-105$ \\
\hline Mean BP & 91.26 & 13.4 & $65-130$ \\
\hline Pulse oximetry & 98.32 & 1.9 & $94-100$ \\
\hline
\end{tabular}

There were a total of 33 observations of oral care; 22 within 48 hours of continuous ICP monitoring and 11 repeated in the same subject within 72-96 hours of continuous monitoring. In twenty-four observations (73\%), patients were intubated; two patients had a tracheostomy. Twenty-four of 25 patients with artificial airways were mechanically ventilated. The average length of stay on the day of the observation was $5.85(\mathrm{SD}=6.26)$ with a range of 1-24 days. The average number of days that the catheter had been in place on the day of the observation was $4.88(\mathrm{SD}=5.95)$ with a range of $1-24$ days. Continuous intravenous sedation was administered in $73 \%$ of the observations; continuous intravenous narcotic analgesia in $42 \%$ of the observations. In 3 observations (10\%), patients were receiving oral narcotic analgesic agents as needed. Intravenous sedatives and analgesics were titrated to effect; no patients received additional doses of sedatives or narcotics before, during or within 5 minutes after oral care. Intravenous vasoconstrictors (phenylephrine and/or norepinephrine) were administered in $24 \%$ of observations, intravenous vasodilators (nicardipine) were administered in $6 \%$ of observations. In 4 observations, patients were receiving continuous infusions of neuromuscular blocking agents. Oral nimodipine, 30mg-60mg every 2 hours was administered in $24 \%$ of the observations, other oral antihypertensive medications in $27 \%$. 


\section{Oral Care Intervention}

The equipment and products used to provide oral care included toothbrushes, toothettes (foam swabs), toothpaste, mouthwash, water, chlorhexidine, normal saline and a 1.5\% hydrogen peroxide solution. Frequencies are shown in Table 4. During a single oral care intervention, nurses always used more than one of the products to clean and rinse the mouth.

\section{Table 4. Oral Care Products Used}

\begin{tabular}{|l|c|c|}
\hline Products & Frequency & \%* $^{*}$ \\
\hline Toothbrush & 20 & 61 \\
\hline Foam Swab (toothette) & 22 & 67 \\
\hline Toothpaste & 21 & 64 \\
\hline Mouthwash & 15 & 45 \\
\hline Chlorhexidine & 6 & 18 \\
\hline Water & 8 & 24 \\
\hline Hydrogen peroxide & 2 & 6 \\
\hline Normal saline & 1 & 3 \\
\hline
\end{tabular}

*Total percent does not equal 100 because multiple products may have been used.

During oral care the mean $\mathrm{HOB}$ elevation was 29.4 degrees $(\mathrm{SD}=12.25)$. The majority of patients were in a supine position with the head and neck in a neutral position (91\%). When the patients were in a right or left side lying position the neck was also turned to the same direction in order to maintain alignment. The mean duration of oral care was 97.45 seconds (SD 55.86). The shortest duration was 24 seconds, the longest 228 seconds ( 3 minutes, 48 seconds). The most common intensity score was 3 (58\%) followed by scores of 2 and 4 (18\% each) and 1 and 5 (3\% each).

Mean ICP values were calculated for each patient 5 minutes before oral care, during oral care and 5 minutes after oral care or until another intervention was performed, whichever came first . Although nurses were asked to avoid additional nursing interventions during the study period, this was not always possible. One patient was endotracheally suctioned during oral care; 
2 patients suctioned immediately following oral care. Because suctioning is known to increase ICP (Gemma et al, 2002; Brucia \& Rudy, 1996; Crosby \& Parsons, 1992; Kerr et al, 1993) and the purpose of this study was to isolate the effect of oral care, data obtained during and after suctioning were not included in the analysis.

Mean (SD) ICP values were 11.37 (6.39), 12.79 (6.01) and 13.33 (7.35) before, during and after oral care, respectively (Figure 4). In 32 of the 33 observations, patients had a mean baseline normal ICP $(<20 \mathrm{mmHg})$ when oral care was initiated. A mixed effect repeated measures ANOVA model indicated that there was a significant difference in ICP values in response to oral care $(p=0.0031)$. There was no significant increase in ICP before to during oral care $(p=0.0551)$ or during to after oral care $(p=0.4859)$. There was a significant mean increase of $2.13 \mathrm{mmHg}$ in ICP from before to after oral care $(p=0.0026)$. There was no statistically significant difference in CPP before, during and after oral care $(p=0.3529)$ Furthermore, there was no clinically significant effect on CPP; no vasoactive medication infusions were adjusted during or after oral care in order to maintain predetermined CPP targets. The least squares mean differences across time points for both ICP and CPP are shown in Table 5. 


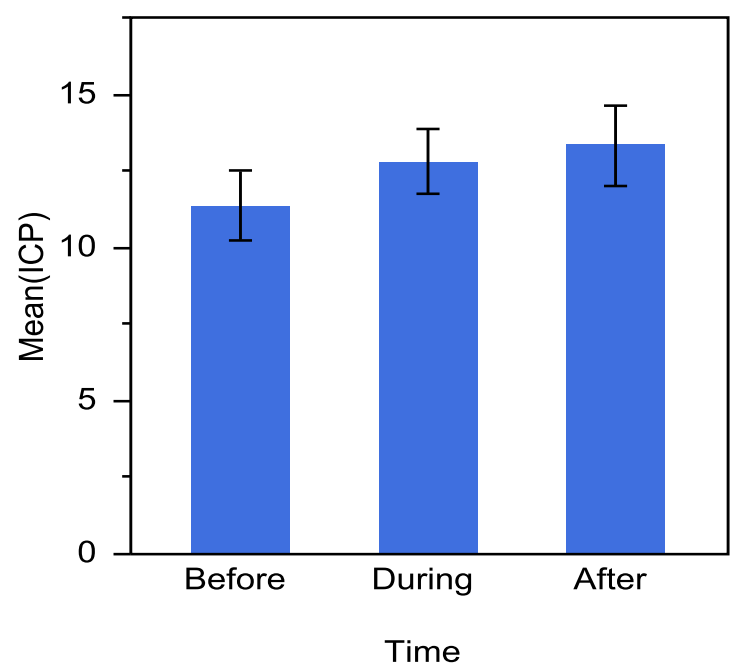

Figure 4. Mean ICP Before, During, and After Oral Care

There were statistically significant differences in heart rate $(p=0.0066)$ and diastolic blood pressure $(p=0.0009)$ across time points. The mean heart rate increased by 3.34 beats/minute from before to during oral care and 4.13 beats/minute from before to after oral care. The mean diastolic blood pressure increased by $2.91 \mathrm{mmHg}$ from before to during oral care and $3.35 \mathrm{mmHg}$ from before to after oral care. These differences were not clinically significant and did not require intervention. There were no statistically significant differences in systolic blood pressure $(p=0.1594)$, respiratory rate $(p=0.4316)$, or pulse oximetry $(p=0.4877)$ in response to oral care. 
Table 5. LS Mean Differences in ICP and CPP Before, During and After Oral Care

\begin{tabular}{|l|c|c|c|}
\hline Variable & $\begin{array}{c}\text { Mean } \\
\text { Difference } \\
(\mathrm{mmHg})\end{array}$ & $\begin{array}{c}\text { 95\% Cl of mean difference } \\
(\mathrm{mmHg})\end{array}$ & $p$-value \\
\hline ICP & & & \\
\hline 5 minutes before to during & 1.42 & $-0.02,2.87$ & 0.0551 \\
\hline During to 5 minutes after & 0.70 & $-0.76,2.17$ & 0.4859 \\
\hline 5 minutes before to 5minutes after & 2.13 & $0.66,3.59$ & $\mathbf{0 . 0 0 2 6}$ \\
\hline CPP & & & 0.3268 \\
\hline 5 minutes before to during & 1.54 & $-1.03,4.11$ & 0.8576 \\
\hline During to 5 minutes after & 0.57 & $-2.03,3.17$ & 0.6455 \\
\hline 5 minutes before to 5minutes after & 0.97 & $-1.63,3.57$ & \\
\hline
\end{tabular}

Multiple linear regression was used to test the relationship between oral care duration and intensity and the change in ICP from before to after oral care. There was no significant relationship found between the ICP change and oral care duration $(p=0.5687)$ or ICP change and oral care intensity $(p=0.9154)$.

There was no relationship between actigraphy values and subjective intensity ratings $(p=0.6403)$. However, patterns in the data were similar to those found in the pilot study and examples are shown in Figure 5. 

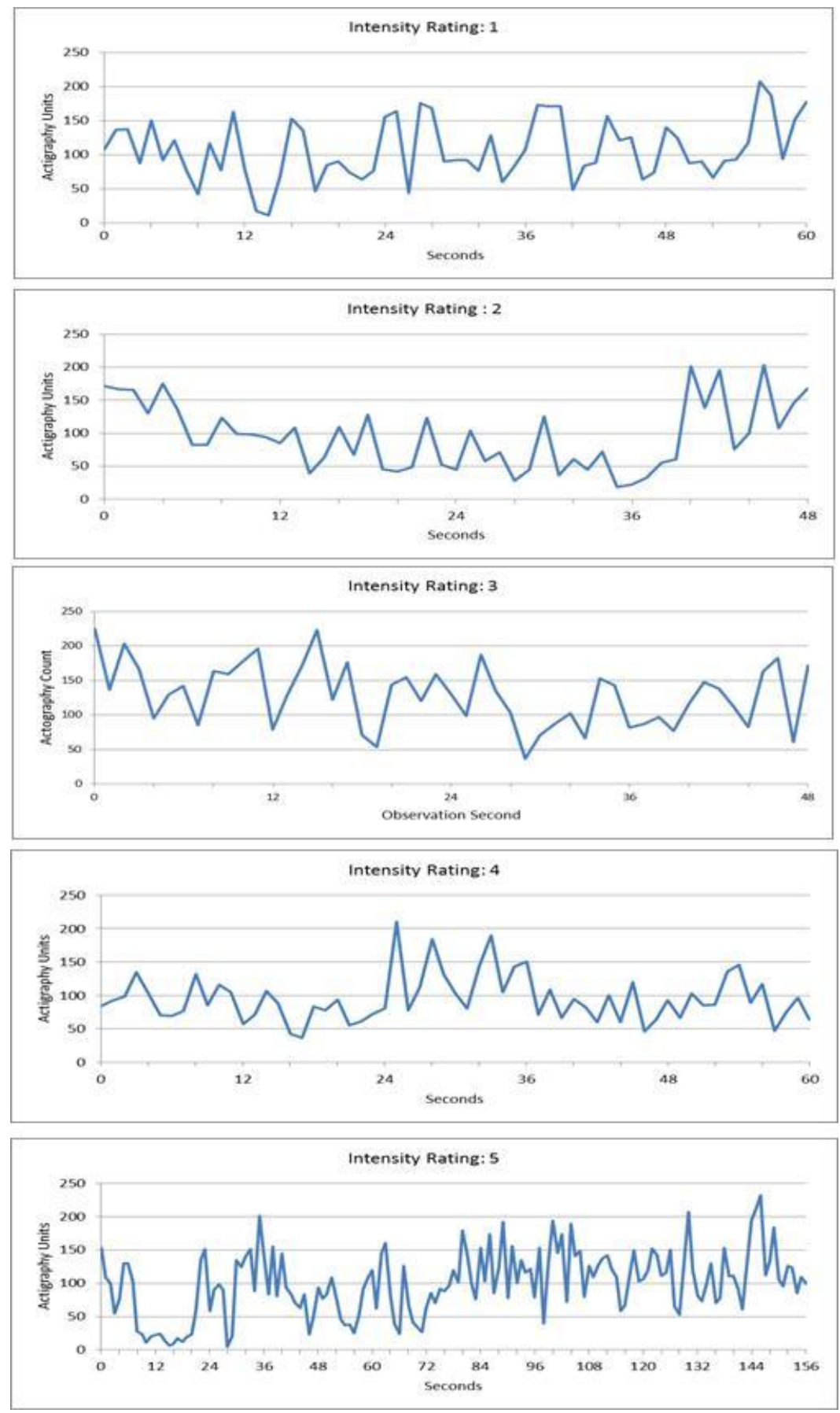

Figure 5. Examples of nurses' wrist actigraphy recordings during oral care by observational rating. Actigraphy count is the total for each 1-second epoch. 


\section{Discussion}

To our knowledge, this is the first study that isolates oral care as an intervention in neuroscience patients and specifically describes the characteristics of the intervention. In this study, oral care appears to have a small but statistically significant effect on ICP. Fluctuations in ICP are expected during nursing interventions. Tsementzis, Harris and Loizou (1982) found significant elevations in ICP in response to nursing care activities. With exception of elevations noted during endotracheal suctioning, the elevations were small and reversible. Snyder (1983) also found significant increases in ICP in response to nursing activities, likewise noting a larger mean increase during endotracheal suctioning. In both of these studies, oral care was included as a nursing activity but it was not specifically described. Bruya (1981) found that oral care produced a small increase in mean ICP from 15 to 16.11 but oral care was bundled with endotracheal suctioning. Hugo (1987) found overall mean ICP increases of 1-27 mmHg in response to nursing interventions. In this study the interventions were specified and again the largest mean increase was related to suctioning. In response to oral care, Hugo specifically found a mean increase in ICP of $12 \mathrm{mmHg}$ that persisted for 294 seconds (4 minutes, 54 seconds).

Nurse-administered oral care in this study varied widely and did not have a particular pattern. It usually started with a toothbrush or toothette but some patients had their lips suctioned prior to oral care even though there was no liquid present. Once the toothbrush (or toothette) was inserted, the teeth and gums were rubbed with various degrees of vigor. Some nurses moved the endotracheal tube to access the oral cavity while others cleaned around it. When brushing was completed, some nurses rinsed the oral cavity with a toothette soaked in mouthwash, water, peroxide or normal saline or a combination of these products. Some nurses rinsed the mouth 
using a saline or mouthwash filled syringe to inject fluid into the oral cavity. Oral suctioning occurred multiple times during the intervention.

The study sample was small and though there was a statistically significant difference in ICP in response to oral care, there were no clinically significance changes in response to oral care; the intervention was generally well tolerated. As previously mentioned, 2 patients did require suctioning during oral care. It is unclear whether oral care evoked coughing either by direct stimulation of a cough or gag reflex or through manipulation of the endotracheal tube. In the one patient with a baseline elevated ICP, all routine nursing interventions were performed at the bedside nurses' discretion. In this patient there was a mean increase in ICP from before to during oral care of $5 \mathrm{mmHg}$. The ICP continued to rise following oral care with a mean increase from before to after of $16 \mathrm{mmHg}$. Oral care intensity in this patient was 3 and the duration was moderate at 84 seconds; GCS before and after oral care was 8 . This was the first time the patient received oral care therefore the nurse was unable to predict the ICP response to this intervention.

In this study, the mean ICP increase during oral care from baseline was $2 \mathrm{mmHg}$. In patients with a normal ICP this increase does not pose a problem. In patients whose ICP is already elevated however, a change of $2 \mathrm{mmHg}$ may be clinically relevant.

The findings in this study are similar to those of Prendergast and colleagues (2011) in which the effect of manual and electric toothbrushing on ICP among intubated patients was studied. Our study differed from Prendergast in that we used both observational and actigraphy evaluation of intensity of nurse-administered oral care. We did not control for oral care products or duration whereas the Prendergast study used either a manual or electric tooth brush and the protocol for oral care duration was 2 minutes. In our study, mean values were calculated using data acquired at 12 second epochs 5 minutes before, during and 5 minutes after oral care whereas 
Prendergast used the mean ICP and CPP recorded by the bedside nurse 30 minutes before, during, and 30 minutes after oral care. While both studies found small but statistically significant increases in ICP in response to oral care, the differences in design and data collection must be considered when comparing the results of the two studies.

\section{Conclusion}

ICP monitoring in patients with neurological injuries has been a central focus for neuroscience clinicians for over four decades. ICP monitoring provides valuable information for the treatment of patients with intracranial pathology including traumatic brain injury, subarachnoid hemorrhage, cerebral edema, infection, and mass lesions (Thompson, 2011). ICP values, along with the neurological examination and other physiological measures are useful in predicting outcomes and worsening pathology as well for guiding medical and surgical therapies (Bratton et al., 2007). Nursing care of critically ill neuroscience patients is also based on the ICP and, more specifically, on the nurse's judgment about the patient's ICP response to nursing interventions (McNett, et al. 2010). As with all nursing interventions provided to patients with acute neurological injury, the need to perform oral care must be weighed against the risk for causing increased ICP. This study provides evidence that nurse-administered oral care, regardless of intensity and duration, does not adversely effect ICP in the absence of preexisting elevated ICP. 
References 


\section{References}

Acebo, C. \& LeBourgeois, M.K. (2006). Actigraphy. Respiratory Care Clinics of North America, 12, 23-30. doi:10.1016/j.rcc.2005.11.010

American Association of Critical-Care Nurses (2010, April). Practice alert: Oral care for patients at risk for ventilator-associated pneumonia. Retrieved from http://www.aacn.org/ WD/Practice/Docs/ PracticeAlerts/oral\%20care\%2004-2010\%20final.pdf

Ames, N.J. (2011). Evidence to support tooth brushing in critically ill patients. American Journal of Critical Care, 20, 242-250. doi:10.4037/ajcc2011120

Arts, D.G.T., de Keiser, N.F., Vroom, M.B., \& deJonge, E. (2005). Reliability and accurace of Sequential Organ Failure Assessment (SOFA) scoring. Critical Care Medicine, 33, 19881993. doi:10.1097/01.CCM.0000178178.02574.AB

Berry, A. M. \& Davidson, P. M. (2006). Beyond comfort: oral hygiene as a critical nursing activity in the intensive care unit. Intensive \& Critical Care Nursing, 22, 318-328. doi:10.1016/j.iccn.2006.04.003

Berry, A. M., Davidson, P. M., Masters, J., \& Rolls, K. (2007). Systematic literature review of oral hygiene practices for intensive care patients receiving mechanical ventilation. American Journal of Critical Care, 16(6), 552-563.

Binkley, C., Furr, A., Carrico, R., \& McCurren, C. (2004). Survey of oral care practices in US intensive care units. American Journal of Infection Control, 32, 161-169. doi:10.1016/j.ajic.2003.05.001

Boss, B. J. (2002). Concepts of neurologic dysfunction. In K.L.McCance \& S. E. Huether (Eds.), Pathophysiology: The biological basis for disease in adults and children (4th ed., pp. 438-486). St. Louis: Mosby.

Branston, N.M. (1995). The physiology of the cerebrovascular parasympathetic innervation. British Journal of Neurosurgery, 9(3), 319-329. 
Bratton, S.L., Chestnut, R.M., Ghajar, J., Connell Hammond, F.F, Harris, O.A., Hartl, Manley, G.T., Nemecek, A., Newell, D.W., Rosenthal, G., Schouten, J., Shutter, L., Timmons, S.D., Ullman, J.S., Videtta, W., Wilberger, J.E., \& Wright, D.W. (2007). Guidelines for the management of severe traumatic brain injury. VI. Indications for intracranial pressure monitoring. Journal of Neurotrauma, 24 (Supplement 1), S37-S44.

doi:10.089/neu.2007.9990

Breedlove, S.M. (2007) General principles of sensory processing, touch and pain. In S.M.Breedlove, M. R., Rosenzweig, \& N. V. Watson (Eds.), Biological psychology: An introduction to behavioral, cognitive and clinical neuroscience (5th ed., pp. 217-247). Sunderland, MA: Sinauer Associates, Inc.

Brucia, J. \& Rudy, E. (1996). The effect of suction catheter insertion and tracheal stimulation in adults with severe brain injury. Heart \& Lung: The Journal of Critical Care, 25(4), 295303.

Bruya, M. A. (1981). Planned periods of rest in the intensive care unit: nursing care activities and intracranial pressure. Journal of Neurosurgical Nursing, 13(4) 184-194.

Claydon, N. C. (2008). Current concepts in toothbrushing and interdental cleaning. Periodontology 2000, 48, 10-22. Retrieved from http://www.mendeley.com/research/ current-concepts-in-toothbrushing-and-interdental-cleaning/

Crosby, L. J. \& Parsons, L. C. (1992). Cerebrovascular response of closed head-injured patients to a standardized endotracheal tube suctioning and manual hyperventilation procedure. Journal of Neuroscience Nursing, 24(1), 40-49

Donkin, J.J., \& Vink, R. (2010). Mechanisms of cerebral edema in traumatic brain injury: therapeutic developments. Current Opinion in Neurology, 23, 293-299. doi:10.1097/WCO.0b013e3283371451

Fan, J. (2004). Effect of backrest position on intracranial pressure and cerebral perfusion pressure in individuals with brain injury: a systematic review. Journal of Neuroscience Nursing, 36(5), 278-288.

Ferreira, F.L., Bota, D.P., Bross, A., Melot, C. \& Vincent, J.L. (2001). Serial evaluation of the SOFA score to predict outcome in critically ill patients. Journal of the American Medical Association, 286(14), 1754-1758.

Frattalone, A.R. \& Stevens, R.D. (2011). Intracranial pressure and its surrogates. Intensive Care Medicine, 37, 1051-1053. doi:10.1007/s00134-011-2224-2

Gemma, M., Tommasino, C., Cerri, M., Giannotti, A., Piazzi, B., \& Borghi, T. (2002). Intracranial effects of endotracheal suctioning in the acute phase of head injury. Journal of Neurosurgical Anesthesiology, 14(1), 50-54. 
Grap, M.J., Borchers, C.T., Munro, C.L., Elswick, R.K., \& Sessler, C.N. (2005). Actigraphy in the critically ill: Correlation with activity, agitation and sedation. American Journal of Critical Care, 14(1), 52-60.

Grap, M. J., Munro, C. L., Ashtiani, B., \& Bryant, S. (2003). Oral care interventions in critical care: frequency and documentation. American Journal of Critical Care, 12(2), 113-119.

Hanneman, S. K. \& Gusick, G. M. (2005). Frequency of oral care and positioning of patients in critical care: a replication study. American Journal of Critical Care, 14(5), 378-387.

Hendrickson, S. L. (1987). Intracranial pressure changes and family presence. Journal of Neuroscience Nursing, 19(1), 14-17.

Hickey, J. V. \& Olson, D. M. (2009). Intracranial hypertension: Theory and management of increased intracranial pressure. In J.V.Hickey (Ed.), The clinical practice of neurological and neurosurgical nursing (6th ed., pp. 270-307). Philadelphia: Lippincott Williams \& Wilkins.

Hugo, M. (1987). Alleviating the effects of care on the intracranial pressure (ICP) of head injured patients by manipulating nursing care activities. Intensive Care Nursing, 3(2), 7882.

Hugo, M. (1992). Left or right, up or down: a case for positioning of unconscious head-injured patients. Curationis, 15(1), 1-7.

Institute for Healthcare Improvement Ventilator Bundle: Daily Oral Care with Chlorhexidine (2009). Retrieved from http://www.ihi.org/knowledge/Pages/Changes/DailyOralCarewith Chlorhexidine.aspx

Johnson, S. M., Omery, A., \& Nikas, D. (1989). Effects of conversation on intracranial pressure in comatose patients. Heart \& Lung, 18(1), 56-63.

Jones, B. (1994). The effects of patient repositioning on intracranial pressure. Australian Journal of Advanced Nursing, 12(4), 32-39.

Jones, H., Newton, J. T., \& Bower, E. J. (2004). A survey of the oral care practices of intensive care nurses. Intensive \& Critical Care Nursing: The Official Journal of the British Association of Critical Care Nurses, 20, 69-76. doi:10.1016/j.iccn.2004.01.004

Kandel, E. R., Schwartz, J. H., \& Jessell, T. M. (2000). Principles of neural science. (4th ed.) New York: McGraw-Hill.

Kerr, M. E., Rudy, E. B., Brucia, J., \& Stone, K. S. (1993). Head-injured adults: recommendations for endotracheal suctioning. Journal of Neuroscience Nursing, 25(2), 86-91. 
Kerr, M. E., Rudy, E. B., Weber, B. B., Stone, K. S., Turner, B. S., Orndoff, P. A. et al. (1997). Effect of short-duration hyperventilation during endotracheal suctioning on intracranial pressure in severe head-injured adults. Nursing Research, 46(4), 195-201.

Leidy, N.K., Abbott, R.D., \& Fefenko, K.M. (1997). Sensitivity and reproducibility of the dualmode actigraphy under controlled levels of activity intensity. Nursing Research, 46(1), $5-11$.

Lipe, H. P. \& Mitchell, P. H. (1980). Positioning the patient with intracranial hypertension: how turning and head rotation affect the internal jugular vein. Heart \& Lung: The Journal Of Critical Care, 9(6), 1031-1037.

March, K., \& Madden, L. (2009). Intracranial pressure management. In L.R. Littlejohns \& M.K. Bader, M.K. (Eds), AACN-AANN protocols for practice: Monitoring technologies in critically ill neuroscience patients (pp. 35-69). Sudsbury, MA: Jones \& Bartlett.

March, K., Mitchell, P., Grady, S., \& Winn, R. (1990). Effect of backrest position in intracranial and cerebral perfusion pressures. Journal of Neuroscience Nursing, 22(6), 375-381.

May, K. (2009). The pathophysiology and causes of raised intracranial pressure. British Journal of Nursing, 18(5), 911-914.

McNett, M., Dohney, M., Sedlak, C. A., \& Ludwick, R. (2009). Judgments of critical care nurses about risk for secondary brain injury. American Journal of Critical Care, 19,250-260. doi:10.4037/ajec2009293

Mitchell, P. H. (1986). Intercranial hypertension: influence of nursing care activities. Nursing Clinics of North America, 21(4), 563-575.

Mitchell, P. H. \& Mauss, N. K. (1978). Relationship of patient-nurse activity to intracranial pressure variations: a pilot study. Nursing Research, 27(1), 4-10.

Mitchell, P. H., Ozuna, J., \& Lipe, H. P. (1981). Moving the patient in bed: effects on intracranial pressure. Nursing Research, 30(4), 212-218.

Munro, C. L. \& Grap, M. J. (2004). Oral health and care in the intensive care unit: state of the science. American Journal of Critical Care, 13(1), 25-33.

Munro, C.L., Grap, M.J., Jones, D.J., McClish, D.K., \& Sessler, C.N. (2009). Chlorhexidine, toothbrushing, and preventing ventilator-associated pneumonia in critically ill adults. American Journal of Critical Care, 18, 428-437. doi:10.4037/ajcc2009792

Ng, I., Lim, J., \& Wong, H. B. (2004). Effects of head posture on cerebral hemodynamics: its influences on intracranial pressure, cerebral perfusion pressure, and cerebral oxygenation. Neurosurgery, 54, 593-597. doi:10.1227/01.NEU.0000108639.16783.39 
Olson D.M., Thoyre, S.M, Bennett, S.N.,Stoner, J.B., \& Graffagnino C. (2009). Effect of mechanical chest percussion on intracranial pressure: a pilot study. American Journal of Critical Care, 18, 330-335. doi:10.4037/ajcc2009523

Olson, D. M., Thoyre, S. M., Turner, D. A., Bennett, S., \& Graffagnino, C. (2007). Changes in intracranial pressure associated with chest physiotherapy. Neurocritical Care, 6, 100-103. doi:10.1007/s12028-007-0015-y

Parsons, L. C., Peard, A. L., \& Page, M. C. (1985). The effects of hygiene interventions on the cerebrovascular status of severe closed head injured persons. Research in Nursing \& Health, 8(2), 173-181.

Parsons, L. C. \& Wilson, M. M. (1984). Cerebrovascular status of severe closed head injured patients following passive position changes. Nursing Research, 33(2), 68-75.

Prendergast, V., Hagell, P., \& Hallberg, I. R. (2011). Electric versus manual tooth brushing among neuroscience ICU patients: Is it safe? Neurocritical Care, 14, 281-286. doi:10.1007/s12028-011-9502-2

Prendergast, V., Hallberg, I. R., Jahnke, H., Kleiman, C., \& Hagell, P. (2009). Oral health, ventilator-associated pneumonia, and intracranial pressure in intubated patients in a neuroscience intensive care unit. American Journal of Critical Care, 18, 368-376. doi:10.4037/ajcc2009621

Prins, M. M. (1989). The effect of family visits on intracranial pressure. Western Journal of Nursing Research, 11, 281-292. doi:10.1177/019394598901100303

Ropper, A. H. \& Rockhoff, M. A. (1993). Physiology and clinical aspects of raised intracranial pessure. In A.H.Ropper (Ed.), Neurological and neurosurgical intensive care (3rd ed., pp. 11-27). New York: Raven Press, Ltd.

Schinner, K. M., Chisholm, A. H., Grap, M. J., Siva, P., Hallinan, M., \& LaVoice-Hawkins, A. M. (1995). Effects of auditory stimuli on intracranial pressure and cerebral perfusion pressure in traumatic brain injury. Journal of Neuroscience Nursing, 27(6), 348-354.

Schwarz, S. M., Georgiadis, D. M., Aschoff, A. M., \& Schwab, S. M. (2002). Effects of body position on intracranial pressure and cerebral perfusion in patients with large hemispheric stroke. Stroke, 33(2), 497-501. Retrieved from http://www.stroke.ahajournals.org/ content/33/2/497.full.pdf

Simmons, B. J. (1997). Management of intracranial hemodynamics in the adult: a research analysis of head positioning and recommendations for clinical practice and future research. Journal of Neuroscience Nursing, 29(1), 44-49.

Snyder, M. (1983). Relation of nursing activities to increases in intracranial pressure. Journal of Advanced Nursing, 8(4), 273-279. 
Szabo, C \& Munro, C.L. (2010, February). Oral care practices of neuroscience nurses. Poster session presented at the meeting of the Southern Nurses Research Society, Jacksonville, FL. Abstract retrieved from http://www.resourcenter.net/images/SNRS/Files/2011/ AnnMtg/AbstractProceedings/start.htm

Szabo,C. M. (2011). The effect of oral care on intracranial pressure: A review of the literature. Journal of Neuroscience Nursing, 43, E1-E9. doi:10.1097/JNN.0b013e318227f1e5

Thompson, H.J. (Ed.). (2011). American Association of Neuroscience Nurses Reference series for Clinical Practice. Care of the patient undergoing intracranial pressure monitoring/external ventricular drainage or lumbar drainage. Retrieved from http://www.aann.org/ uploads/ AANN11_ICPEVDnew.pdf

Treloar, D. M., Nalli, B. J., Guin, P., \& Gary, R. (1991). The effect of familiar and unfamiliar voice treatments on intracranial pressure in head-injured patients. The Journal of Neuroscience Nursing: Journal of the American Association of Neuroscience Nurses, 23(5), 295-299.

Tsementzis, S. A., Harris, P., \& Loizou, L. A. (1982). The effect of routine nursing care procedures on the ICP in severe head injuries. Acta Neurochirurgica, 65, 153-166. doi: $10.1007 / \mathrm{BF} 01405841$

Vincent, J.L., de Mendonca, A., Cantraine, F., Moreno, R. Takala, J. Suter, P.M., Sprung, C.L. Colardyn, F., \& Belcher, S. (1998). Use of the SOFA score to assess the incidence of organ dysfunction/failure in intensive care units: Results of a multicenter prospective study. Crtical Care Medicine, 26(11), 1793-1800.

Walker, J. S., Eakes, G. G., \& Siebelink, E. (1998). The effects of familial voice interventions on comatose head-injured patients. Journal of Trauma Nursing: The Official Journal of the Society of Trauma Nurses, 5(2), 41-45.

Williams, A. \& Coyne, S. M. (1993). Effects of neck position on intracranial pressure. American Journal of Critical Care: An Official Publication, American Association of Critical-Care Nurses, 2(1), 68-71.

Winkelman, C. (2000). Effect of backrest position on intracranial and cerebral perfusion pressures in traumatically brain-injured adults. American Journal of Critical Care, 9(6), $373-382$.

Wojner, A. W., El-Mitwalli, A., \& Alexandrov, A. V. (2002). Effect of head positioning on intracranial blood flow velocities in acute ischemic stroke: a pilot study. Critical Care Nursing Quarterly, 24(4), 57-66.

Wojner-Alexander, A. W., Garami, Z., Chernyshev, O. Y., \& Alexandrov, A. V. (2005). Heads down: flat positioning improves blood flow velocity in acute ischemic stroke. Neurology, 64, 1354-1357. doi: 10.1212/01.WNL.0000158284.41705.A 
Wolfe, T.J. \& Torbey, M.T. (2009). Management of intracranial pressure. Current Neurology and Neuroscience Reports, 9, 477-485. Retrieved from http://www.med.unc.edu/neurology/neurocritical-care/docs/ICP/WolfeManagement $\% 20$ of\%20intracranial\%20pressure-Curr\%20Neurol\%20Neurosci\%20Rep2009.pdf

Zygun, D.A., Doig, C.J., Gupta, A.K., Whiting, G., Nicholas, E.S., Conway-Smith, C., \& Menon, D.K. (2003). Non-neurological organ dysfunction in neurocritical care. Journal of Critical Care, 18, 238-244. doi:10.1016/j.jcrc.2003.10.007 


\section{Vita}

Christina Marie Szabo was born on February 3, 1957, in Cincinnati, Ohio, and is an American citizen. She graduated from Glen Este High School, Glen Este, Ohio in 1975. She received her Diploma of Nursing from the Christ Hospital School of Nursing in 1977. She received her Bachelor of Science in Nursing from Virginia Commonwealth University, Richmond, Virginia in 1998 and her Master of Science in Nursing in 2003. She has worked as an ICU nurse for 37 years. 